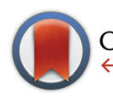

CrossMark \&lick for update

Cite this: Inorg. Chem. Front., 2014, 1,621

Received 11th July 2014,

Accepted 30th July 2014

DOI: 10.1039/c4qi00094c

rsc.li/frontiers-inorganic

\title{
Explosive Werner-type cobalt(III) complexes $\uparrow+$
}

\author{
Raik Deblitz, ${ }^{a}$ Cristian G. Hrib, ${ }^{a}$ Steffen Blaurock, ${ }^{a}$ Peter G. Jones, \\ Georg Plenikowski ${ }^{c}$ and Frank T. Edelmann*a
}

\begin{abstract}
A series of potentially explosive Werner-type cobalt(III) complexes comprising the anions azotetrazolate, nitrotetrazolate, picrate and dipicrylamide were prepared via simple metathetical routes. Treatment of $\left[\mathrm{Co}\left(\mathrm{NH}_{3}\right)_{5} \mathrm{NO}_{2}\right] \mathrm{Cl}_{2}$, trans- $\left[\mathrm{Co}\left(\mathrm{NH}_{3}\right)_{4}(\mathrm{py}) \mathrm{NO}_{2}\right] \mathrm{Cl}_{2}$ (py = pyridine), trans- $\left[\mathrm{Co}\left(\mathrm{NH}_{3}\right)_{4}\left(\mathrm{NO}_{2}\right)_{2}\right] \mathrm{Cl}$, and [Co $\left.\left(\mathrm{NH}_{3}\right)_{5} \mathrm{~N}_{3}\right] \mathrm{Cl}_{2}$ with equimolar amounts of disodium azotetrazolate, $\left(\mathrm{Na}_{2} \mathrm{C}_{2} \mathrm{~N}_{10} \cdot 5 \mathrm{H}_{2} \mathrm{O}\right.$, 1), in aqueous solutions afforded new cobalt(III) azotetrazolate salts $\left[\mathrm{Co}\left(\mathrm{NH}_{3}\right)_{5} \mathrm{NO}_{2}\right]\left(\mathrm{C}_{2} \mathrm{~N}_{10}\right) \cdot 2 \mathrm{H}_{2} \mathrm{O}$ (2), trans- $\left[\mathrm{Co}\left(\mathrm{NH}_{3}\right)_{4}(\right.$ py)$\left.\mathrm{NO}_{2}\right]\left(\mathrm{C}_{2} \mathrm{~N}_{10}\right) \cdot 2 \mathrm{H}_{2} \mathrm{O}(3)$, trans- $\left[\mathrm{Co}\left(\mathrm{NH}_{3}\right)_{4}\left(\mathrm{NO}_{2}\right)_{2}\right]_{2}\left(\mathrm{C}_{2} \mathrm{~N}_{10}\right)(4)$, and $\left[\mathrm{Co}\left(\mathrm{NH}_{3}\right)_{5} \mathrm{~N}_{3}\right]\left(\mathrm{C}_{2} \mathrm{~N}_{10}\right) \cdot \mathrm{H}_{2} \mathrm{O}$ (5) in moderate to excellent yields (46-88\%). Similar treatment of trans- $\left[\mathrm{Co}\left(\mathrm{NH}_{3}\right)_{4}\left(\mathrm{NO}_{2}\right)_{2}\right] \mathrm{Cl}$ with 1 equiv. of sodium 5-nitrotetrazolate dihydrate (= NaNT, 6) afforded the novel cobalt(III) 5-nitrotetrazolate derivative trans$\left[\mathrm{Co}\left(\mathrm{NH}_{3}\right)_{4}\left(\mathrm{NO}_{2}\right)_{2}\right](\mathrm{NT}) \cdot \mathrm{H}_{2} \mathrm{O}$ (7) as orange, rectangular prismatic crystals in $64 \%$ yield. Two complex cobalt(III) picrates, trans- $\left[\mathrm{Co}\left(\mathrm{NH}_{3}\right)_{4}\left(\mathrm{NO}_{2}\right)_{2}\right]$ (picrate) $\cdot \mathrm{H}_{2} \mathrm{O}(\mathbf{9})$ and $\left[\mathrm{Co}\left(\mathrm{NH}_{3}\right)_{5} \mathrm{~N}_{3}\right]$ (picrate) $)_{2}$ (10), were prepared in a similar manner from the corresponding chloride precursors and equimolar amounts of sodium picrate. The reaction of trans-[Co( $\left.\left(\mathrm{NH}_{3}\right)_{4}\left(\mathrm{NO}_{2}\right)_{2}\right] \mathrm{Cl}$ with sodium dipicrylamide (= NaDPA) in a 1:1 molar ratio gave the first cobalt(III) dipicrylamide, trans-[Co(NH$\left.)_{4}\left(\mathrm{NO}_{2}\right)_{2}\right](\mathrm{DPA}) \cdot \mathrm{H}_{2} \mathrm{O}(\mathbf{1 2})$. Finally, the highly explosive, dark blue-green dichroitic non-electrolyte complex mer-[Co(en) $\left.(\mathrm{py})\left(\mathrm{N}_{3}\right)_{3}\right]$ (13) was formed upon treatment of $\left[\mathrm{Co}(e n)(p y)_{2}\left(\mathrm{NH}_{3}\right) \mathrm{Cl}\right] \mathrm{Cl}_{2} \cdot \mathrm{H}_{2} \mathrm{O}$ with excess $\mathrm{NaN}_{3}$ in hot water (93\% yield). The molecular and crystal structures of $\mathbf{2}, \mathbf{3}, \mathbf{4}, \mathbf{5}, \mathbf{7}, \mathbf{9}, \mathbf{1 0}, \mathbf{1 2}$, and 13 were determined by single-crystal X-ray diffraction. In the solid state, all compounds comprised extensive hydrogen-bonded supramolecular networks. Representative studies of the energetic properties (impact and friction sensitivity, combustion) revealed that some of the new compounds can be classified as primary explosives.
\end{abstract}

\section{Introduction}

Primary explosives are highly sensitive explosive compounds which are used to initiate large amounts of secondary explosives such as 2,4,6-trinitrotoluene $(=\mathrm{TNT})^{1}$ in initiating devices like primers and detonators for commercial and military applications. Historically, one of the first practical primary explosives was mercury fulminate, $\mathrm{Hg}(\mathrm{CNO})_{2}$ ("Knallquecksilber"), which has been widely used for almost 100 years. ${ }^{2}$ Later, mercury fulminate was replaced by lead(II) azide, $\mathrm{Pb}\left(\mathrm{N}_{3}\right)_{2}$, ${ }^{3}$ and several forms of lead styphnate (= LS, Scheme 1$)^{4}$ which have been generally used as primary explosives until today.

${ }^{a}$ Chemisches Institut der Otto-von-Guericke-Universität Magdeburg, Universitätsplatz 2, 39106 Magdeburg, Germany. E-mail: frank.edelmann@ovgu.de;

Fax: (+49)391-6712933

${ }^{b}$ Institut für Anorganische und Analytische Chemie der TU Braunschweig, Hagenring 30, 38106 Braunschweig, Germany

${ }^{c}$ Nammo Germany GmbH, Wilhelm-Dümling-Str. 12, 39218 Schönebeck, Germany $\dagger$ Dedicated to Professor Konrad Seppelt on the occasion of his 70th birthday. \$Electronic supplementary information (ESI) available: ORTEP drawings and complete X-ray crystallographic data for $2,3,4,5,7,9,10,12$, and 13 in PDF and CIF format. CCDC 993736-993744. For ESI and crystallographic data in CIF or other electronic format see DOI: 10.1039/c4qi00094c
However, lead(II) azide shows severe disadvantages such as highly toxic hydroazoic acid, $\mathrm{HN}_{3}$, can be formed under certain conditions, ${ }^{3}$ and the use of all these materials is always associated with lead pollution in the environment. ${ }^{5}$ For this reason, the search for environmentally acceptable ("green") primary explosives is currently a hot topic in this field. ${ }^{6}$ One of the most useful approaches is the development of nitrogenrich energetic compounds based on tetrazole and tetrazine derivatives. ${ }^{7}$ A highly promising candidate that has come out of these research efforts is the recently reported copper(I) 5-nitrotetrazolate (= DBX-1). ${ }^{8}$ Easily prepared DBX-1 has been shown to be one of the best "drop-in" lead(II) azide replacements to date due to its high thermal stability and comparable safety and performance.

Several Werner-type cobalt(III) complexes comprising 5-nitrotetrazolate and related ligands have also been synthesized and reported to have primary explosive properties. In particular the complexes shown in Scheme 2, pentaammine(5cyanotetrazolato- $N^{2}$ )cobalt(III) perchlorate (CP), ${ }^{9}$ pentaammine (4,5-diaminotetrazole- $\left.N^{2}\right)$ cobalt perchlorate, ${ }^{10}$ and tetraamminebis(5-nitrotetrazolato- $N^{2}$ ) cobalt(III) perchlorate (BNCP), ${ }^{11}$ were shown to have suitable energetic properties. However, their perchlorate content makes them unacceptable as alternative 


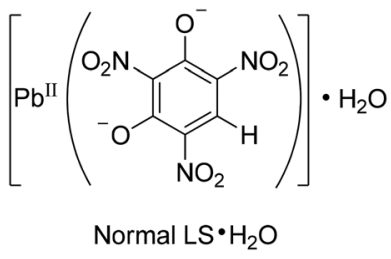

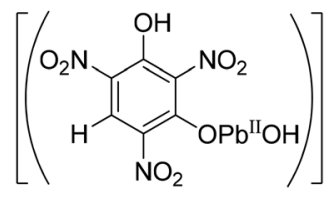

Monobasic LS

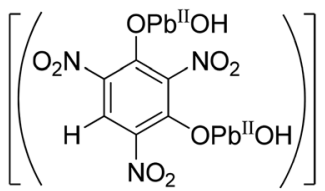

Dibasic LS

Scheme 1

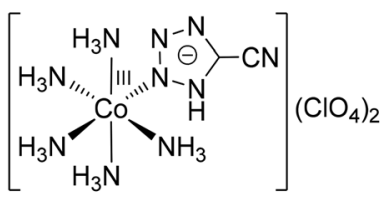

$\mathrm{CP}$

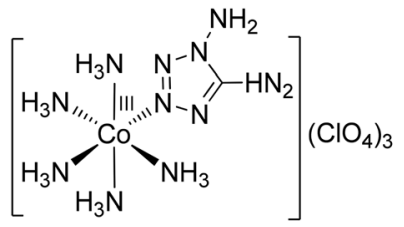

primary explosives because perchlorate has various adverse health effects. ${ }^{12}$

Other potentially explosive Werner-type cobalt(III) complexes have frequently been described in the literature without any practical use. These comprise mainly some long-known azido complexes. While several series of complexes such as [Co$\left.\left(\mathrm{NH}_{3}\right)_{5} \mathrm{~N}_{3}\right]^{2+13}$ cis- and trans- $\left[\mathrm{Co}\left(\mathrm{NH}_{3}\right)_{4}\left(\mathrm{~N}_{3}\right)_{2}\right]^{+},{ }^{14}$ and cis- and trans- $\left[\mathrm{Co}(\mathrm{en})_{2}\left(\mathrm{~N}_{3}\right)_{2}\right]^{+}$(en = ethylene-1,2-diamine $)^{15}$ are often thermally quite stable (with the exception of some azides and perchlorates), there are several cases of highly explosive species. For example, several salts of the $\left[\mathrm{Co}\left(\mathrm{N}_{3}\right)_{6}\right]^{3-}$ anion were found to be quite sensitive to impact and friction, ${ }^{16}$ and the compound trans-tetraammine-diazido-cobalt(III)-trans-diammine-tetraazidocobaltate(III), $\left[\mathrm{Co}\left(\mathrm{NH}_{3}\right)_{4}\left(\mathrm{~N}_{3}\right)_{2}\right]\left[\mathrm{Co}\left(\mathrm{NH}_{3}\right)_{2}\left(\mathrm{~N}_{3}\right)_{4}\right]$, is described as a "dangerous detonator", but its energetic properties have not been studied in detail. ${ }^{17}$ Also notable is the (in)famous green non-electrolyte complex mer-[Co( $\left.\left(\mathrm{NH}_{3}\right)_{3}\left(\mathrm{~N}_{3}\right)_{3}\right]$. It has been reported that this compound is highly impact-sensitive and can even explode upon grinding under water. ${ }^{18}$

In this contribution we report the synthesis, structural characterization, and energetic properties of a series of new explosive Werner-type cobalt(III) complexes. Our synthetic protocol involves combination of complex cobalt(III) cations with various nitrogen-rich or oxygen-rich, sensitive, secondary high explosive anions. For the present study, azotetrazolate, 5-nitrotetrazolate, picrate, and dipicrylamide were chosen as suitable representative energetic anions. Unlike the cobalt(III) complexes depicted in Scheme 2, the new compounds reported here contain the energetic anions in the outer sphere and not directly coordinated to the central $\mathrm{Co}^{3+}$ cation.

\section{Results and discussion}

\section{Azotetrazolates}

The azotetrazolate dianion, $\left(\mathrm{C}_{2} \mathrm{~N}_{10}{ }^{2-}\right)$, has been found to be extremely useful in the design of new nitrogen-rich energetic salts. ${ }^{19}$ The disodium salt $\mathrm{Na}_{2} \mathrm{C}_{2} \mathrm{~N}_{10} \cdot 5 \mathrm{H}_{2} \mathrm{O}$ (1) is the most readily accessible azotetrazolate precursor described in the literature. It was first prepared by Thiele more than 100 years ago by oxidation of aminotetrazole with $\mathrm{KMnO}_{4}$ in boiling sodium hydroxide solution (Scheme 3). This rather harsh method provides disodium azotetrazolate as its pentahydrate in the form of large, bright yellow crystals. ${ }^{20}$

New Werner-type cobalt(III) complexes containing the azotetrazolate anion were synthesized according to Scheme 4 by metathetical reactions of chloride precursors with equimolar amounts of 1. As starting materials, several easily accessible penta- and tetraamminecobalt(III) chlorides containing nitro and azido ligands were chosen $\left(\left[\mathrm{Co}\left(\mathrm{NH}_{3}\right)_{5} \mathrm{NO}_{2}\right] \mathrm{Cl}_{2}\right.$, trans-[Co$\left(\mathrm{NH}_{3}\right)_{4}($ py $\left.) \mathrm{NO}_{2}\right] \mathrm{Cl}_{2}$ (py = pyridine $)$, trans $-\left[\mathrm{Co}\left(\mathrm{NH}_{3}\right)_{4}\left(\mathrm{NO}_{2}\right)_{2}\right] \mathrm{Cl}$, and $\left.\left[\mathrm{Co}\left(\mathrm{NH}_{3}\right)_{5} \mathrm{~N}_{3}\right] \mathrm{Cl}_{2}\right)$.

All reactions illustrated in Scheme 4 were carried out at room temperature in concentrated aqueous solutions. The products $\left[\mathrm{Co}\left(\mathrm{NH}_{3}\right)_{5} \mathrm{NO}_{2}\right]\left(\mathrm{C}_{2} \mathrm{~N}_{10}\right) \cdot 2 \mathrm{H}_{2} \mathrm{O}(2,63 \%$ yield $)$, trans-[Co$\left(\mathrm{NH}_{3}\right)_{4}\left(\right.$ py) $\left.\mathrm{NO}_{2}\right]\left(\mathrm{C}_{2} \mathrm{~N}_{10}\right) \cdot 2 \mathrm{H}_{2} \mathrm{O} \quad(3, \quad 46 \%), \quad$ trans-[Co$\left.\left(\mathrm{NH}_{3}\right)_{4}\left(\mathrm{NO}_{2}\right)_{2}\right]_{2}\left(\mathrm{C}_{2} \mathrm{~N}_{10}\right)(4,87 \%)$, and $\left[\mathrm{Co}\left(\mathrm{NH}_{3}\right)_{5} \mathrm{~N}_{3}\right]\left(\mathrm{C}_{2} \mathrm{~N}_{10}\right) \cdot \mathrm{H}_{2} \mathrm{O}$ $(5,88 \%)$ crystallized within $24 \mathrm{~h}$ upon undisturbed standing of the reaction mixtures. The nitro complexes 2-4 formed yellow to orange crystals, whereas the azido complex $\mathbf{5}$ crystallized in the form of dark red rods. Recrystallization from hot water was possible but not necessary, as the products directly obtained from the original reaction mixtures were already quite pure. Routine characterization was mainly based on IR data and elemental analyses. As expected, these data provided only some basic information on the nature of the products. Thus they will be briefly discussed here only for compound

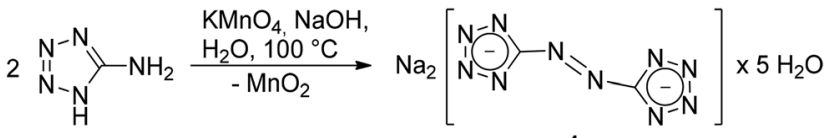

Scheme 3 


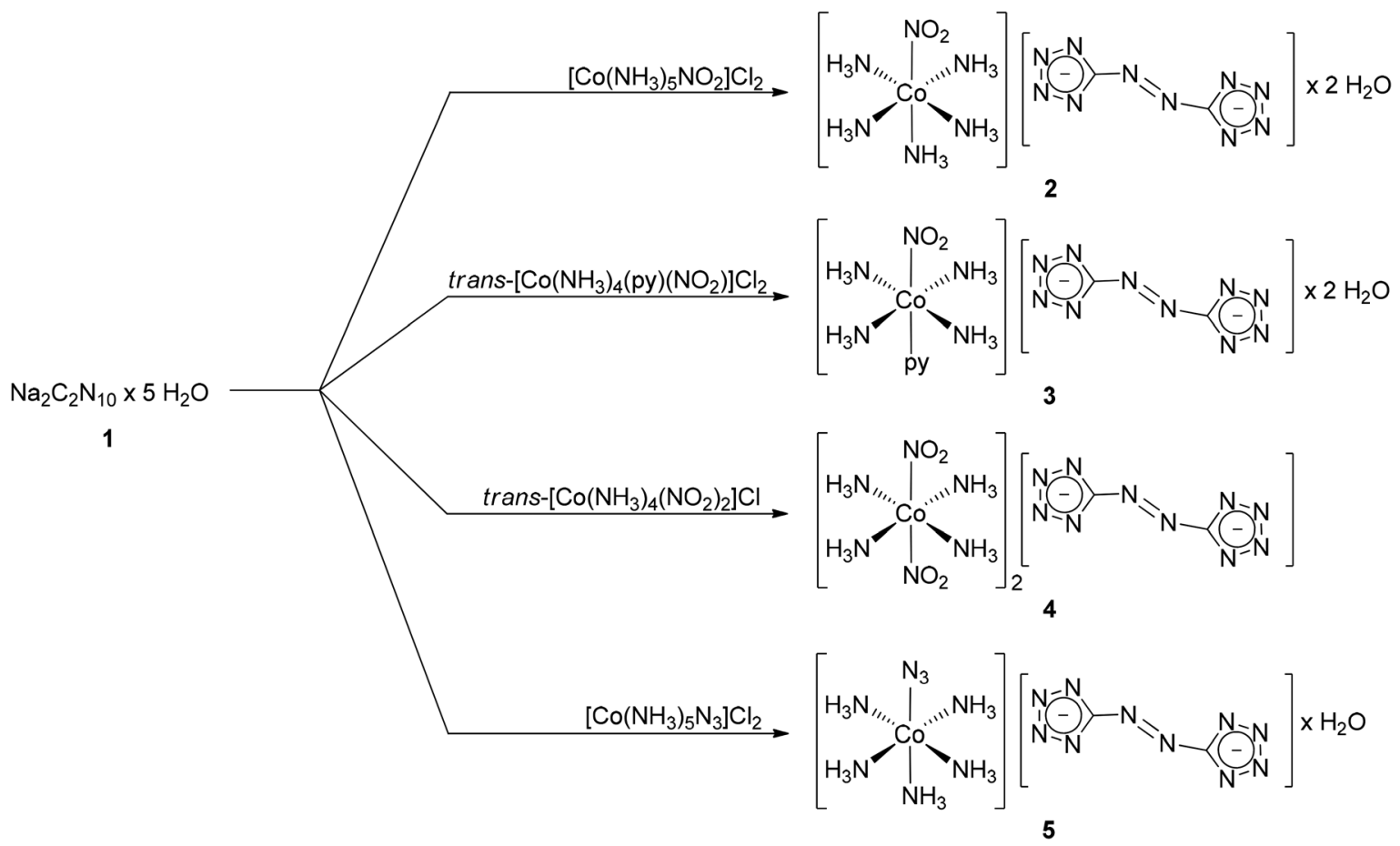

Scheme 4

$\left[\mathrm{Co}\left(\mathrm{NH}_{3}\right)_{5} \mathrm{NO}_{2}\right]\left(\mathrm{C}_{2} \mathrm{~N}_{10}\right) \cdot 2 \mathrm{H}_{2} \mathrm{O}(2)$ as a typical example. Elemental analysis was consistent with the formation of the expected product as the dihydrate. The IR spectrum showed two intense absorptions which are characteristic for the free azotetrazolate dianion. A strong band around $730-740 \mathrm{~cm}^{-1}$ can be assigned to the asymmetrical $\mathrm{C}-\mathrm{N}=\mathrm{N}$ stretching mode of the azo group, whereas a strong band around $1390-1400 \mathrm{~cm}^{-1}$ is attributable to the asymmetrical $\mathrm{N}-\mathrm{C}=\mathrm{N}$ stretching mode of the ring. These characteristic bands are more or less the same in all compounds containing uncoordinated azotetrazolate dianions. ${ }^{19}$ In the IR spectrum of 2 , the two bands appear at 740 and $1402 \mathrm{~cm}^{-1}$. While ${ }^{1} \mathrm{H}$ NMR data were unavailable for the new complexes $\mathbf{2 - 5}$, the presence of uncoordinated azotetrazolate dianions could also be verified by the ${ }^{13} \mathrm{C}$ NMR data, measured in DMSO- $d_{6}$ solutions. In all four cases, the signal of the carbon atom of the azotetrazolate dianion appeared in the ${ }^{13} \mathrm{C}$ NMR spectra at $\delta=173.1$, which is characteristic of saltlike azotetrazolates. ${ }^{19}$ In the ${ }^{13} \mathrm{C}$ NMR spectrum of 3 the signals of the coordinated pyridine could be observed at $\delta=$ 8.4, 7.8, and 7.3.

All four new compounds were also structurally characterized by single-crystal X-ray diffraction. In all cases, suitable single-crystals were obtained directly from the original reaction mixtures. A summary of the crystallographic data and refinement parameters for all nine crystal structures reported in this study is given in Table 1. Fig. 1-12 show photographs of the single-crystals, ORTEP drawings of the molecular structures including selected bond lengths and angles, as well as packing diagrams of the hydrogen-bonded networks in the solid state.
In the solid state, compounds 2-5 consist of the complex cobalt(III) cations and azotetrazolate dianions in the respective stoichiometric ratio plus one (5) or two $(2,3)$ equivalents of water of crystallization. Only the dinitro complex trans-[Co$\left.\left(\mathrm{NH}_{3}\right)_{4}\left(\mathrm{NO}_{2}\right)_{2}\right]_{2}\left(\mathrm{C}_{2} \mathrm{~N}_{10}\right)$ (4) crystallizes water-free. The individual ions display no unusual structural features. The hexacoordinated cobalt(III) cations show no significant deviation from the regular octahedral coordination geometry. Taken as a typical example, the cis- $\mathrm{N}-\mathrm{Co}-\mathrm{N}$ angles in the trans-[Co$\left.\left(\mathrm{NH}_{3}\right)_{4}\left(\mathrm{NO}_{2}\right)_{2}\right]^{+}$cation in 4 are in the very narrow range of 87.86(8)-91.10(7) ${ }^{\circ}$, whereas the trans $-\mathrm{N}-\mathrm{Co}-\mathrm{N}$ angles range from $177.01(6)^{\circ}$ to $179.77(6)^{\circ}$. The central $\mathrm{N}=\mathrm{N}$ double-bond length in the azotetrazolate dianion in 4 is 1.251(3) $\AA$, whereas the $\mathrm{N}-\mathrm{N}$ distances in the tetrazole rings clearly indicate delocalization of the negative charge because of bond homogenization with $\mathrm{N}-\mathrm{N}$ distances of $1.339(2) \AA(\mathrm{N} 2-\mathrm{N} 3), 1.326(2) \AA$ (N3-N4), and 1.342(2) $\mathrm{A}$ (N4-N5) (reference bond lengths: C-N, $1.47 \AA ; \mathrm{N}=\mathrm{N}, 1.24 \AA$; and $\mathrm{N}-\mathrm{N}, 1.47 \AA) .{ }^{19}$ These values are in excellent agreement with those reported in the literature and are also quite uniform within the series of azotetrazolates 2-5. Thus the structural parameters of the remaining three complexes will not be discussed here in more detail. What makes the crystal structures of 2-5 special is the presence of extended hydrogen-bonded networks in the solid state as is illustrated in Fig. 3, 6, 9, and 12. Hydrogen-bonded networks are quite typical for nearly all previously reported salt-like azotetrazolates. ${ }^{19}$ Fig. 12 displays the packing diagram of $\left[\mathrm{Co}\left(\mathrm{NH}_{3}\right)_{5} \mathrm{~N}_{3}\right]$ $\left(\mathrm{C}_{2} \mathrm{~N}_{10}\right) \cdot \mathrm{H}_{2} \mathrm{O}(5)$ as a typical example. It can be seen that the azotetrazolate anions form stacks interconnecting the $\left[\mathrm{Co}\left(\mathrm{NH}_{3}\right)_{5} \mathrm{~N}_{3}\right]^{2+}$ cations. Six of the nitrogen atoms of the tetra- 


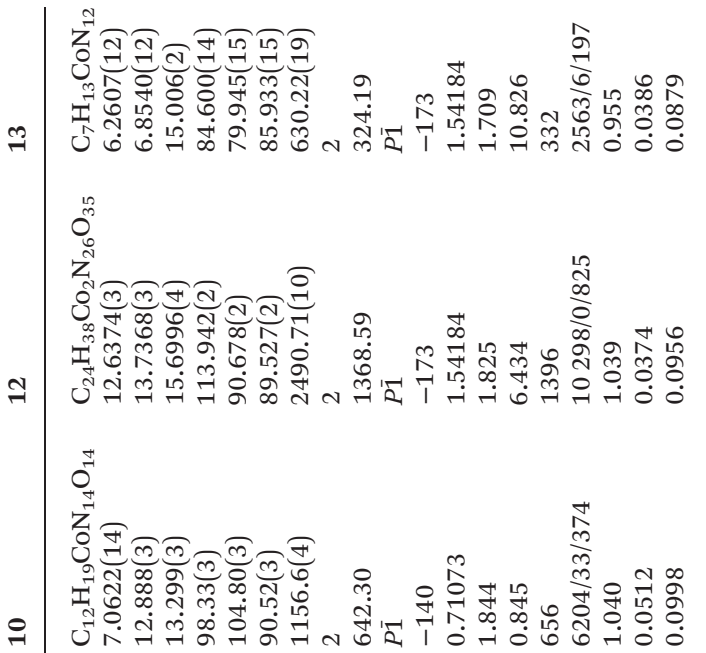

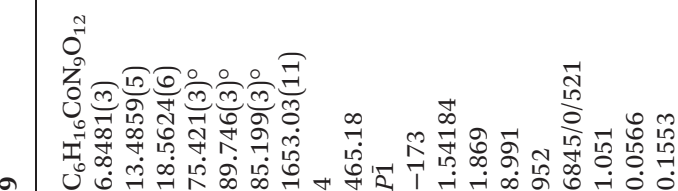

a

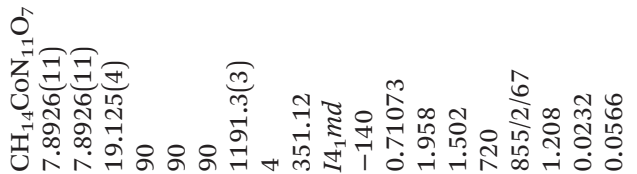

$\wedge$

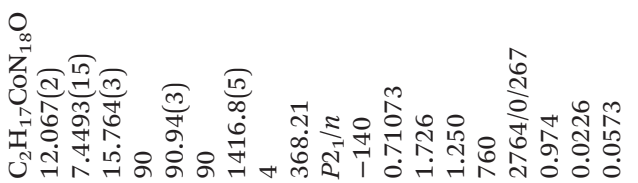

is

$\overbrace{\substack{N \\ \text { N }}}^{\infty}$

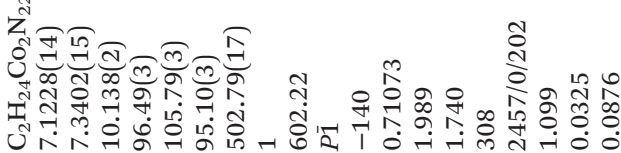

$\rightarrow$

물

ส่

ㅇำ

a

is

\&

mi

$\stackrel{\text { o }}{2}$

$\frac{\sqrt{2}}{\frac{\pi}{0}}$

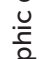

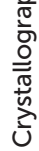

$\frac{\stackrel{0}{0}}{\frac{0}{\circ}}$
$+$

$0_{0}^{+}$

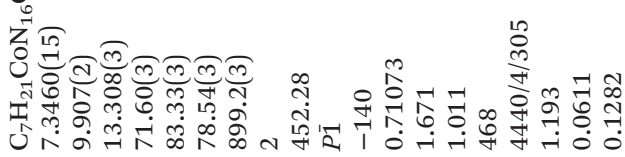

$\infty$

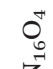

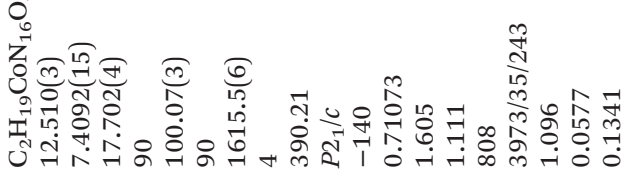

ง

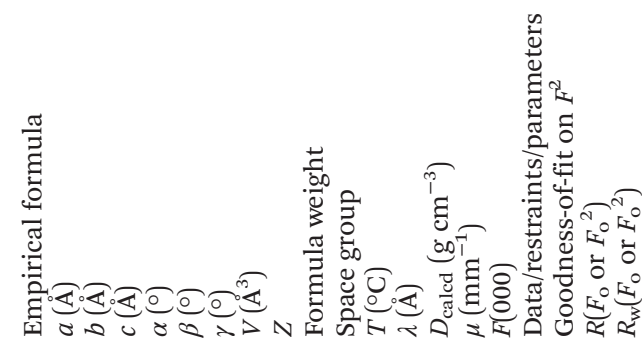

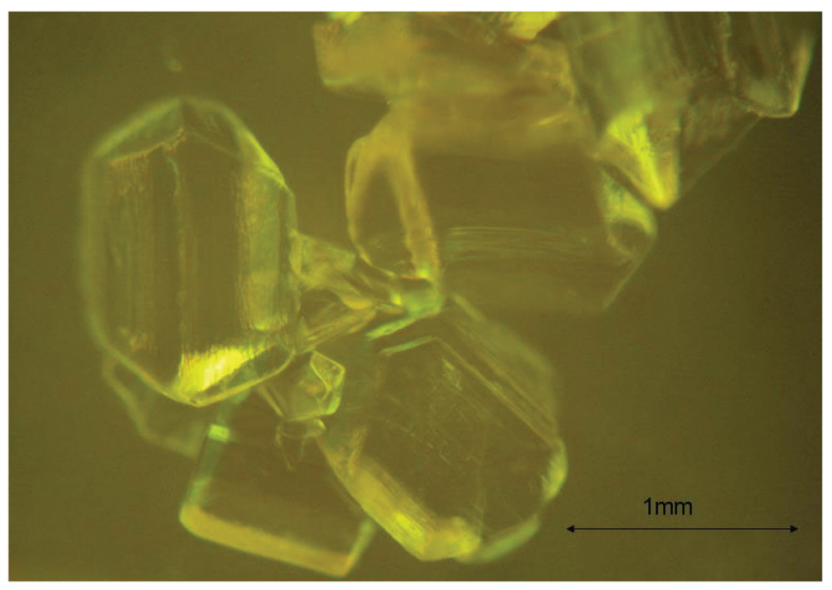

Fig. 1 Single-crystals of $\left[\mathrm{Co}\left(\mathrm{NH}_{3}\right)_{5} \mathrm{NO}_{2}\right]\left(\mathrm{C}_{2} \mathrm{~N}_{10}\right) \cdot 2 \mathrm{H}_{2} \mathrm{O}$ (2).

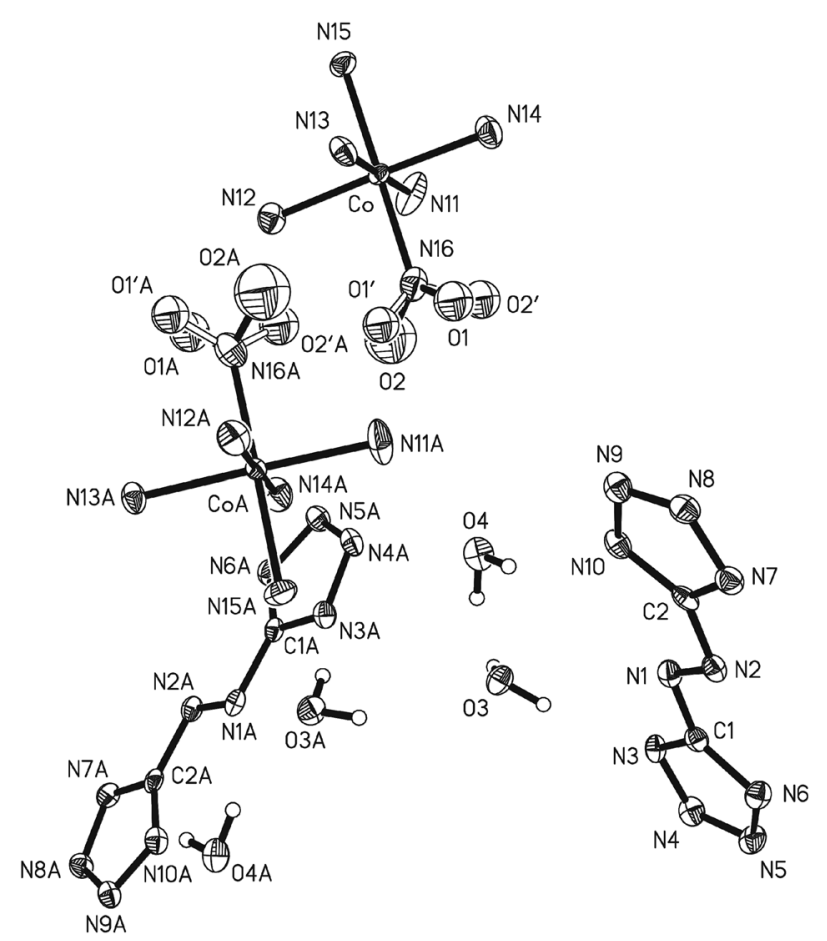

Fig. 2 ORTEP drawing of $\left[\mathrm{Co}\left(\mathrm{NH}_{3}\right)_{5} \mathrm{NO}_{2}\right]\left(\mathrm{C}_{2} \mathrm{~N}_{10}\right) \cdot 2 \mathrm{H}_{2} \mathrm{O}$ (2) at the $50 \%$ probability level. Selected bond lengths (Å) and angles ( $\left(^{\circ}\right)$ : Co-N(13) 1.941(3), Co-N(16) 1.946(4), Co-N(14) 1.949(3), Co-N(11) 1.956(3), Co$\mathrm{N}(12) 1.965(3), \mathrm{Co}-\mathrm{N}(15)$ 1.969(3), N(1)-N(2) 1.252(4), N(1)-C(1) 1.410(5), $\mathrm{N}(2)-\mathrm{C}(2) 1.407(5), \mathrm{N}(2)-\mathrm{N}(1)-\mathrm{C}(1) 112.6(3), \mathrm{N}(1)-\mathrm{N}(2)-\mathrm{C}(2) 111.7(3)$.

zolyl rings are engaged in hydrogen bonding (see Table S12 in the ESI $\$$ ). Four of them (N7, N11, N12, N13, $c f$. Fig. 11) form $\mathrm{N} \cdots \mathrm{H}-\mathrm{N}$ hydrogen bonds in the range of 3.013(2)-3.098(2) $\AA$ with $\mathrm{NH}_{3}$ ligands in the $\left[\mathrm{Co}\left(\mathrm{NH}_{3}\right)_{5} \mathrm{~N}_{3}\right]^{2+}$ cation, while the other

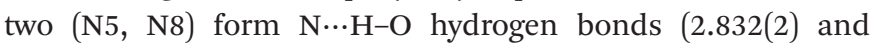
3.044(2) ^) with the water of crystallization. This water molecule obviously plays a central role in this crystal packing as it is also connected to two $\mathrm{NH}_{3}$ ligands in the $\left[\mathrm{Co}\left(\mathrm{NH}_{3}\right)_{5} \mathrm{~N}_{3}\right]^{2+}$ cation $(\mathrm{O} 1 \cdots \mathrm{H}-\mathrm{N} 18$ and $\mathrm{O} 1 \cdots \mathrm{H}-14)$. Full details on the hydro- 


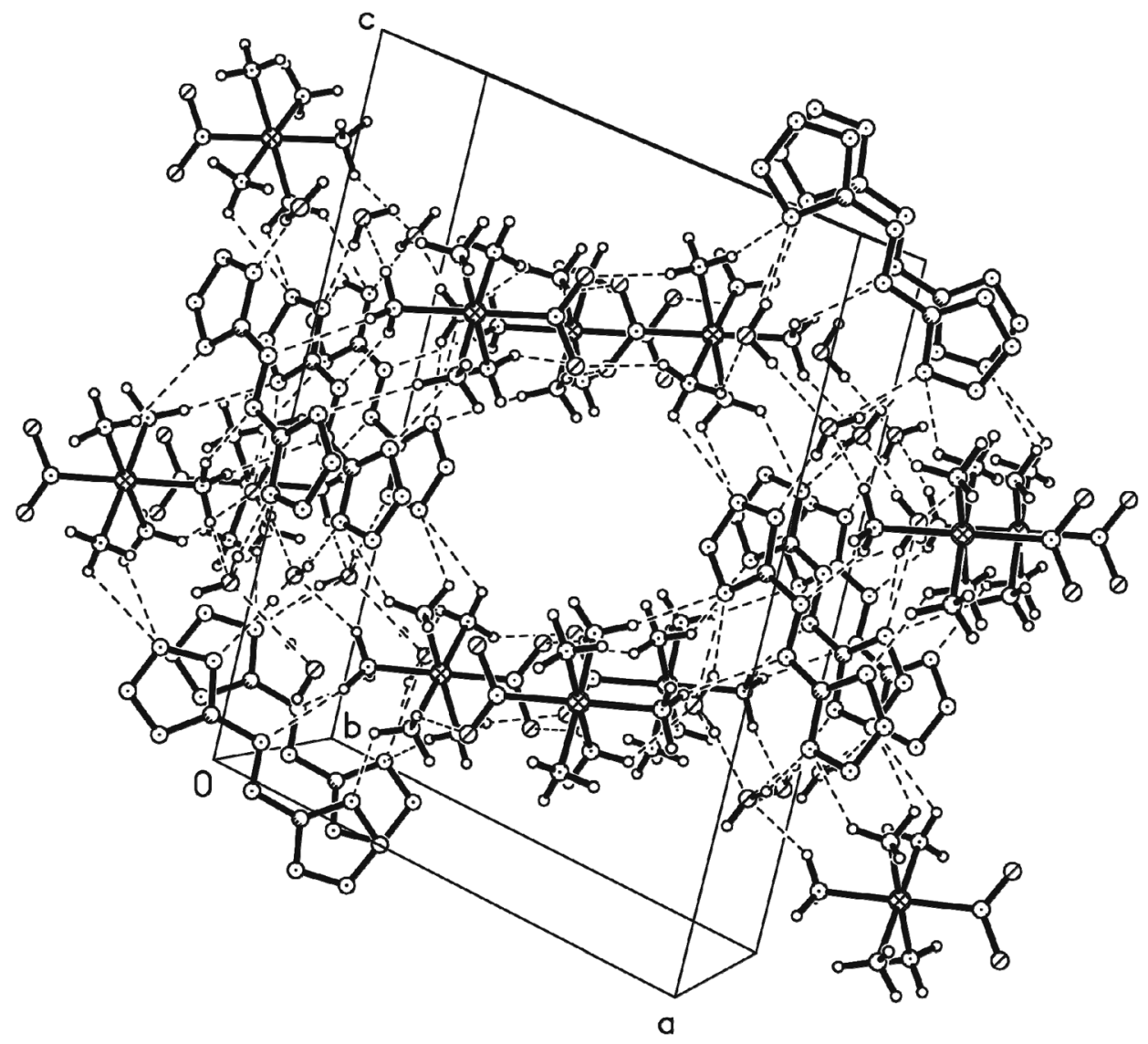

Fig. 3 Packing diagram of $\left[\mathrm{Co}\left(\mathrm{NH}_{3}\right)_{5} \mathrm{NO}_{2}\right]\left(\mathrm{C}_{2} \mathrm{~N}_{10}\right) \cdot 2 \mathrm{H}_{2} \mathrm{O}(2)$. View along the $b$-axis.

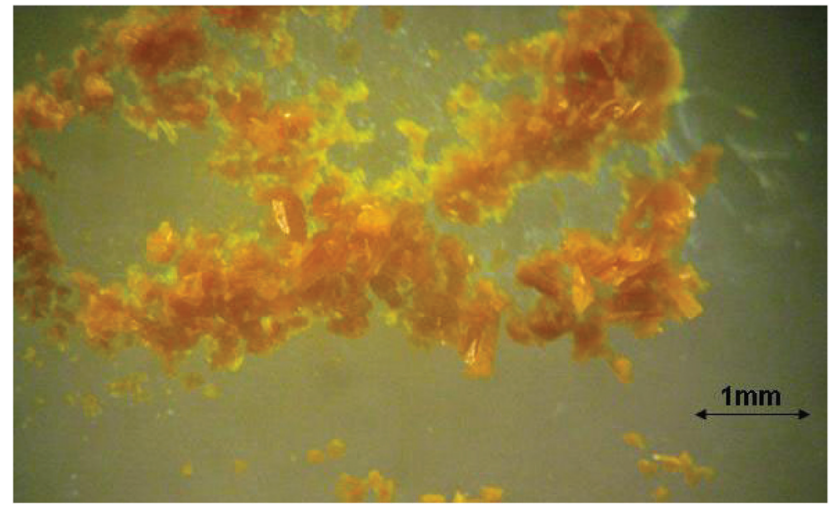

Fig. 4 Single-crystals of $\left[\mathrm{Co}\left(\mathrm{NH}_{3}\right)_{4}(\mathrm{py}) \mathrm{NO}_{2}\right]\left(\mathrm{C}_{2} \mathrm{~N}_{10}\right) \cdot 2 \mathrm{H}_{2} \mathrm{O}(3)$.

gen bonding in all crystal structures reported here can be found in the ESI.t

\section{Nitrotetrazolates}

Explosive materials comprising the 5-nitrotetrazolate anion, $\left[\mathrm{CN}_{4} \mathrm{NO}_{2}\right]^{-}(=\mathrm{NT})$, play an important role in the chemistry and technology of nitrogen-rich energetic materials. Various salts ${ }^{21}$ and transition metal complexes ${ }^{22}$ containing nitrotetrazolate have already been prepared and tested. Recently, we described

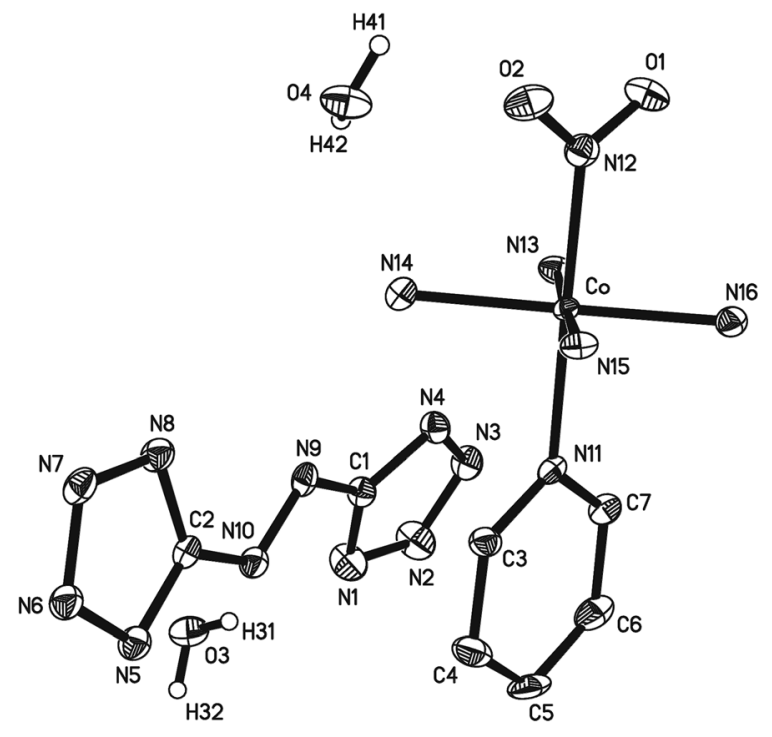

Fig. 5 ORTEP drawing of $\left[\mathrm{Co}\left(\mathrm{NH}_{3}\right)_{4}(\mathrm{py}) \mathrm{NO}_{2}\right]\left(\mathrm{C}_{2} \mathrm{~N}_{10}\right) \cdot 2 \mathrm{H}_{2} \mathrm{O}$ (3) at the $50 \%$ probability level. Selected bond lengths $(\AA)$ and angles ( $\left.{ }^{\circ}\right)$ : Co-N(11) 1.996(3), Co-N(12) 1.899(3), Co-N(13) 1.961(3), Co-N(14) 1.961(3), Co-N(15) 1.961(3), Co-N(16) 1.956(3), N(9)-N(10) 1.261(5), N(9)-C(1) $1.408(5), N(10)-C(2) 1.399(5), N(12)-C o-N(11) 178.98(15), N(10)-N(9)-$ $\mathrm{C}(1) 112.8(3), \mathrm{N}(9)-\mathrm{N}(10)-\mathrm{C}(2) 113.4(3)$. 


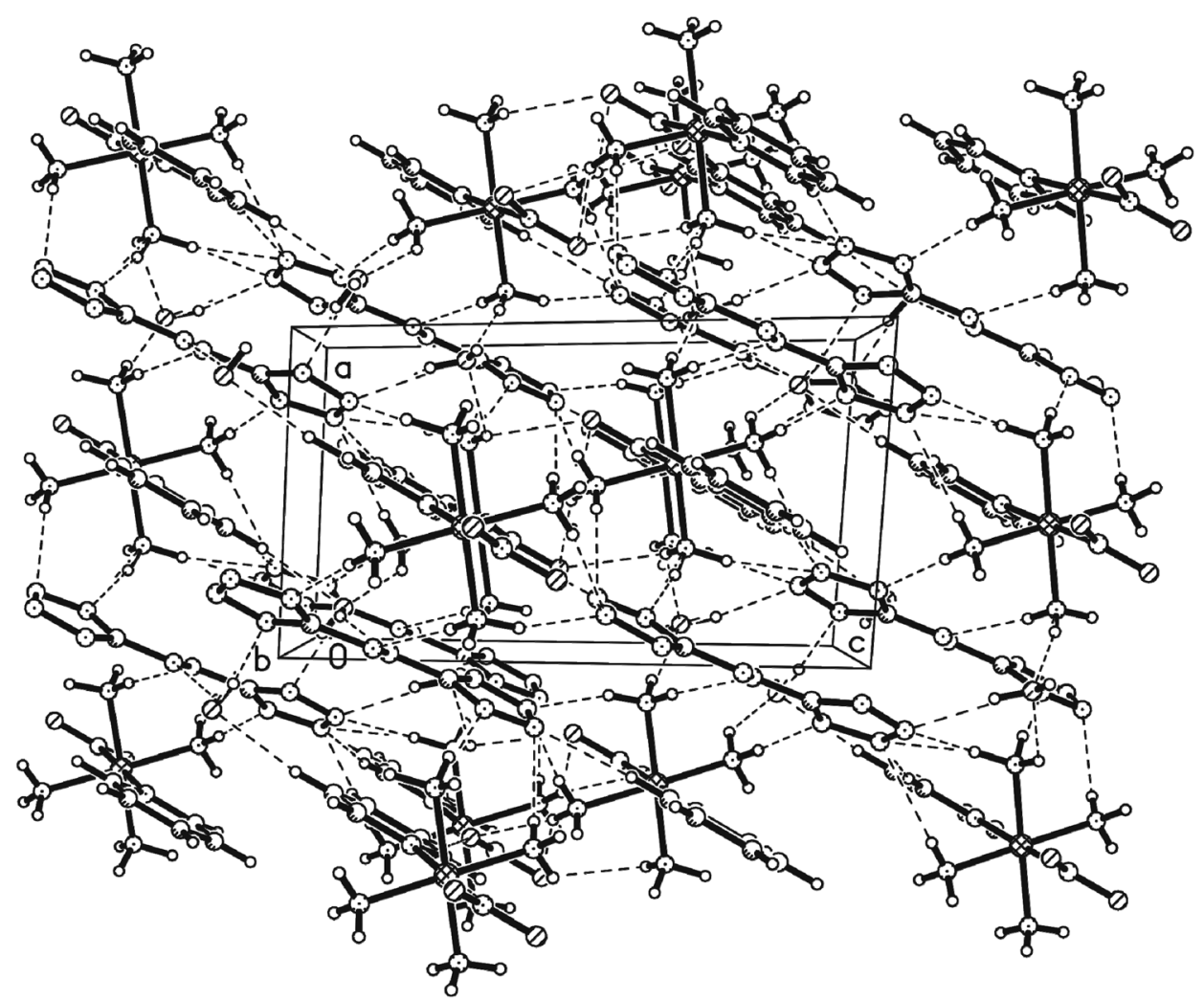

Fig. 6 Packing diagram of $\left[\mathrm{Co}\left(\mathrm{NH}_{3}\right)_{4}(\mathrm{py}) \mathrm{NO}_{2}\right]\left(\mathrm{C}_{2} \mathrm{~N}_{10}\right) \cdot 2 \mathrm{H}_{2} \mathrm{O}$ (3). View along the $b$-axis.

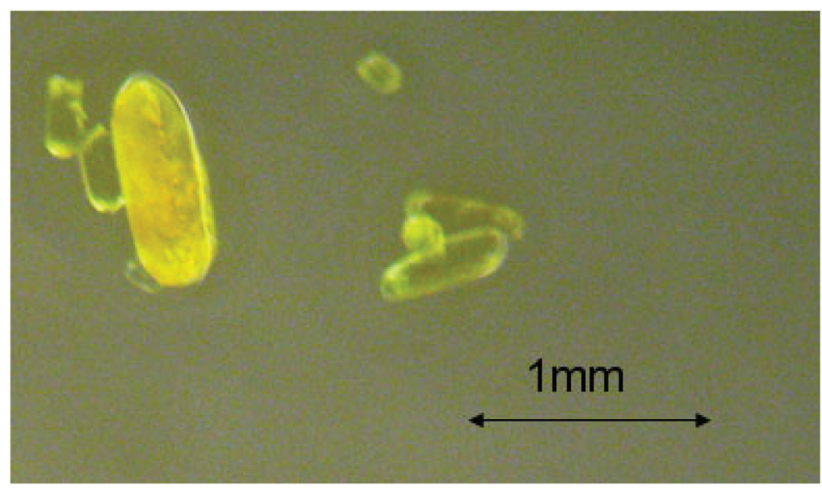

Fig. 7 Single-crystals of trans- $\left[\mathrm{Co}\left(\mathrm{NH}_{3}\right)_{4}\left(\mathrm{NO}_{2}\right)_{2}\right]_{2}\left(\mathrm{C}_{2} \mathrm{~N}_{10}\right)(4)$.

the synthesis, structural characterization, and energetic properties of $\left[\mathrm{Me}_{3} \mathrm{Sn}(\mu-\mathrm{OH}) \operatorname{SnMe}_{3}(\mu-\mathrm{OH}) \operatorname{SnMe}_{3}\left(\mathrm{H}_{2} \mathrm{O}\right)\right][\mathrm{NT}]$ as the first example of a metal-organic main-group metal nitrotetrazolate. ${ }^{23}$ As mentioned above, perhaps the most promising candidate in this area is the recently reported copper(I) 5-nitrotetrazolate $(=\mathrm{DBX}-1){ }^{8}$ Manufacture of DBX-1 involves treatment of copper(II) chloride with sodium 5-nitrotetrazolate dihydrate (= NaNT, 6 ) in the presence of sodium ascorbate as a reducing agent. The synthesis of the important precursor NaNT (6) has been investigated in great detail. ${ }^{21 e, 24}$ For use in this study, NaNT (6) was prepared by a modified literature method according to Scheme $5 .^{21 e, 25}$ The synthesis involves a
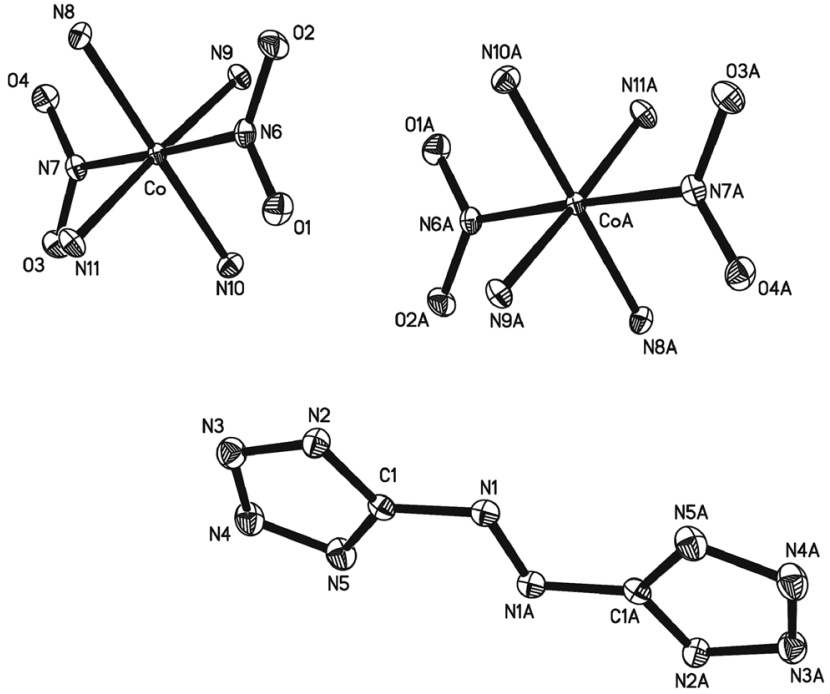

Fig. 8 ORTEP drawing of trans- $\left[\mathrm{Co}\left(\mathrm{NH}_{3}\right)_{4}\left(\mathrm{NO}_{2}\right)_{2}\right]_{2}\left(\mathrm{C}_{2} \mathrm{~N}_{10}\right)(4)$ at the $50 \%$ probability level. Selected bond lengths $[\AA]$ and angles [ $\left.{ }^{\circ}\right]: \mathrm{Co}-\mathrm{N}(7)$ 1.9319(15)Co-N(6) 1.9360(15), Co-N(9) 1.9453(16), Co-N(8) 1.9514(17), Co-N(11) 1.9532(16), Co-N(10) 1.9555(18), C(1)-N(1) 1.405(2), N(1)-N(1) \#1 1.251(3), N(1)\#1-N(1)-C(1) 113.37(18). (\#1 -x+1,-y+1, $-z+2)$.

modified Sandmeyer reaction (diazotization) of 5-aminotetrazole in the presence of copper(II) sulfate. In the first step, a pale blue, very explosive (especially when dry) intermediate of the composition $\mathrm{Cu}(\mathrm{NT})_{2} \cdot \mathrm{HNT}$ is formed, which is kept in a wet 


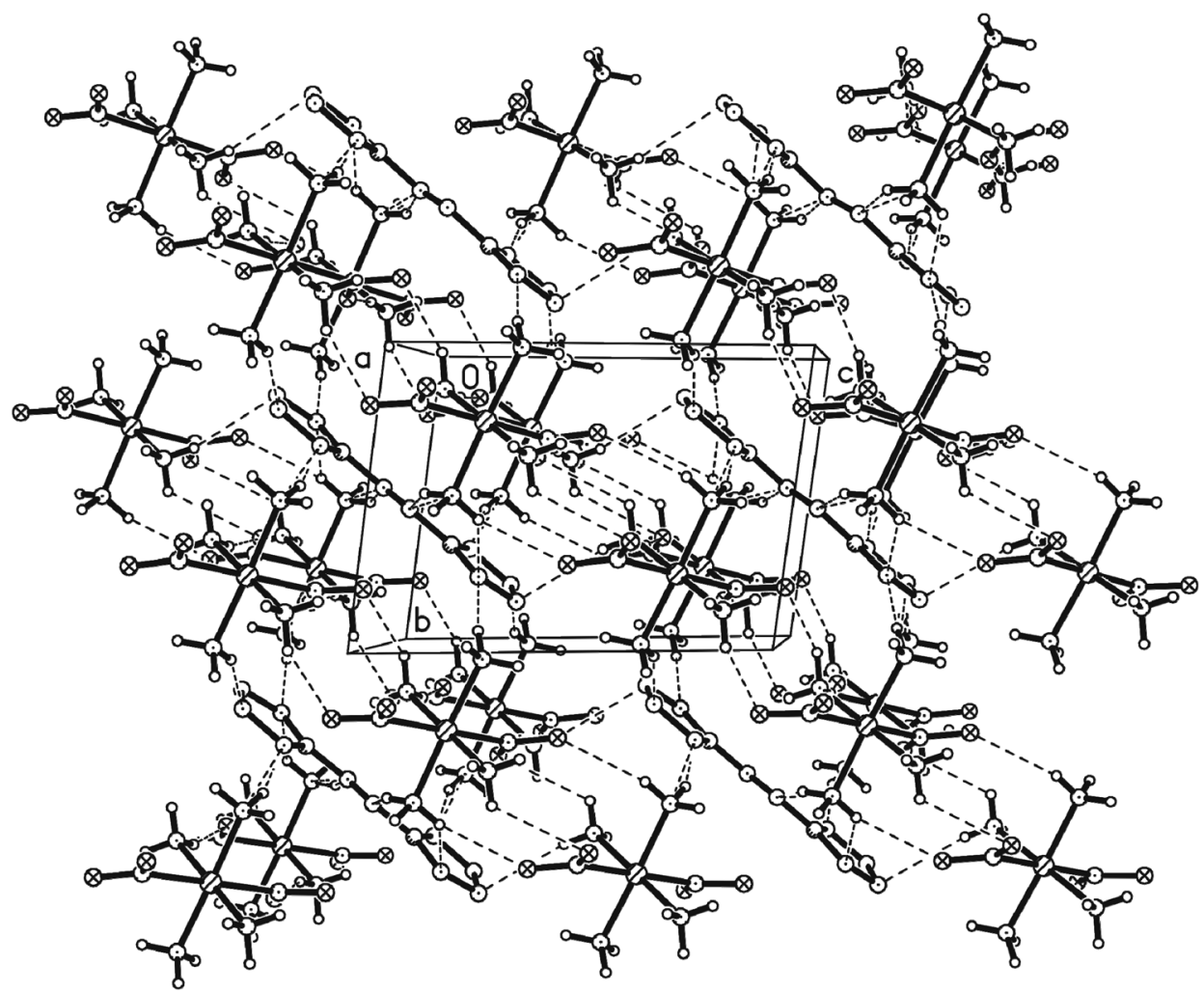

Fig. 9 Packing diagram of trans- $\left[\mathrm{Co}\left(\mathrm{NH}_{3}\right)_{4}\left(\mathrm{NO}_{2}\right)_{2}\right]_{2}\left(\mathrm{C}_{2} \mathrm{~N}_{10}\right)$ (4). View along the a-axis.

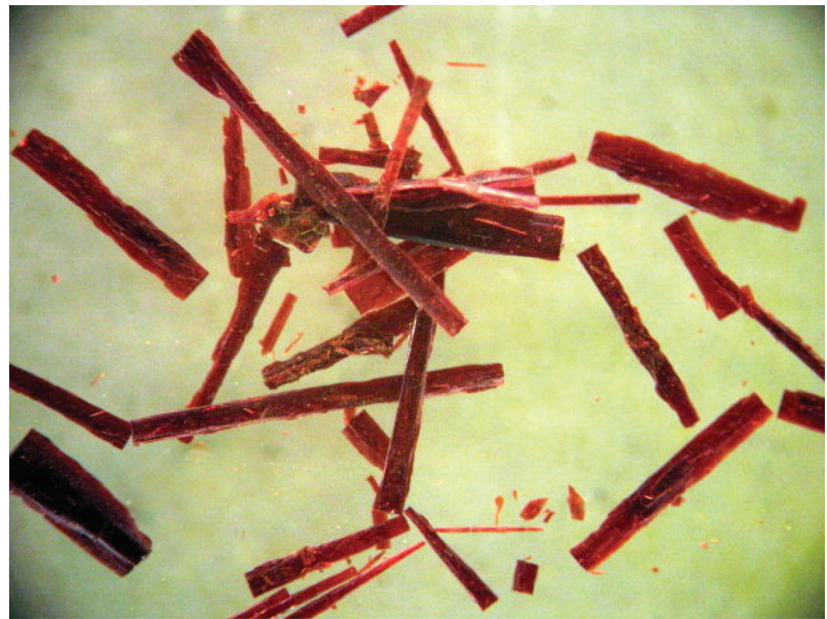

Fig. 10 Single-crystals of $\left[\mathrm{Co}\left(\mathrm{NH}_{3}\right)_{5} \mathrm{~N}_{3}\right]\left(\mathrm{C}_{2} \mathrm{~N}_{10}\right) \cdot \mathrm{H}_{2} \mathrm{O}(5)$.

state and subsequently treated with warm sodium hydroxide solution to afford $\mathbf{6}$ as the dihydrate. While the dihydrate of NaNT is fairly insensitive and can be handled with appropriate care, the anhydrous material is dangerously explosive. ${ }^{21 e, 25}$ Most recently, a significantly improved preparation of highpurity NaNT has been published, which avoids the handling of the potentially dangerous $\mathrm{Cu}(\mathrm{NT})_{2} \cdot \mathrm{HNT}$ intermediate. ${ }^{24 c}$

In the course of the present study, the first cationic Wernertype cobalt(III) ammine complex containing 5-nitrotetrazolate

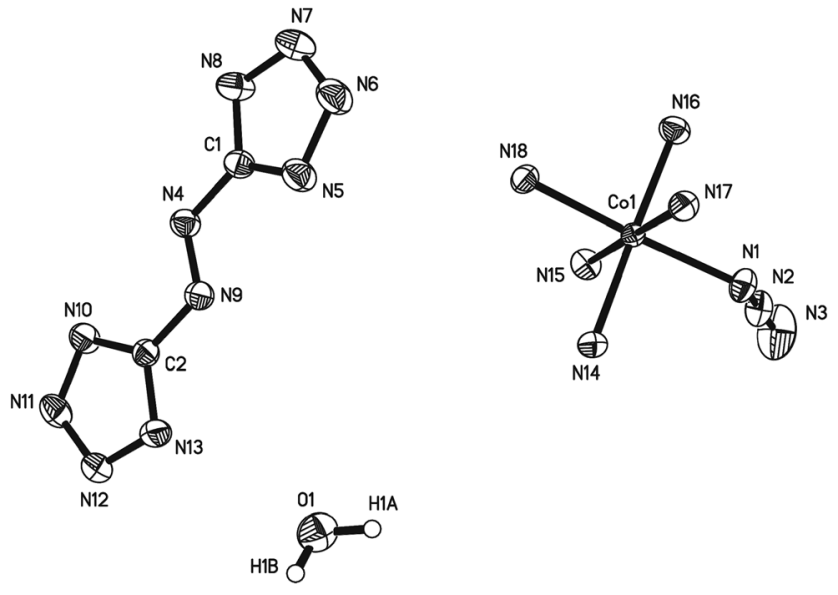

Fig. 11 ORTEP drawing of $\left[\mathrm{Co}\left(\mathrm{NH}_{3}\right)_{5} \mathrm{~N}_{3}\right]\left(\mathrm{C}_{2} \mathrm{~N}_{10}\right) \cdot \mathrm{H}_{2} \mathrm{O}$ (5) at the $50 \%$ probability level. Selected bond lengths [Å] and angles [ $\left.{ }^{\circ}\right]$ : $\mathrm{Co}(1)-\mathrm{N}(14)$ 1.9496(13), Co(1)-N(1) 1.9550(14), Co(1)-N(17) 1.9566(13), Co(1)-N(18) 1.9637(14), Co(1) $-\mathrm{N}(16)$ 1.9758(14), Co(1) $-\mathrm{N}(15)$ 1.9804(14), N(4)-N(9) 1.2553(18), N(4)-N(9)-C(2) 113.09(12), N(9)-N(4)-C(1) 112.34(13).

as the counterion, i.e. not directly coordinated to the central $\mathrm{Co}^{3+}$ ion (cf. Scheme 2), was prepared according to Scheme 6 . Combination of aqueous solutions of equimolar amounts of trans- $\left[\mathrm{Co}\left(\mathrm{NH}_{3}\right)_{4}\left(\mathrm{NO}_{2}\right)_{2}\right] \mathrm{Cl}$ and sodium 5-nitrotetrazolate dihydrate $(=$ NaNT, 6) afforded the novel cobalt(III) 5-nitrotetrazolate derivative trans-[Co( $\left.\left(\mathrm{NH}_{3}\right)_{4}\left(\mathrm{NO}_{2}\right)_{2}\right](\mathrm{NT}) \cdot \mathrm{H}_{2} \mathrm{O}(7)$ as orange, 


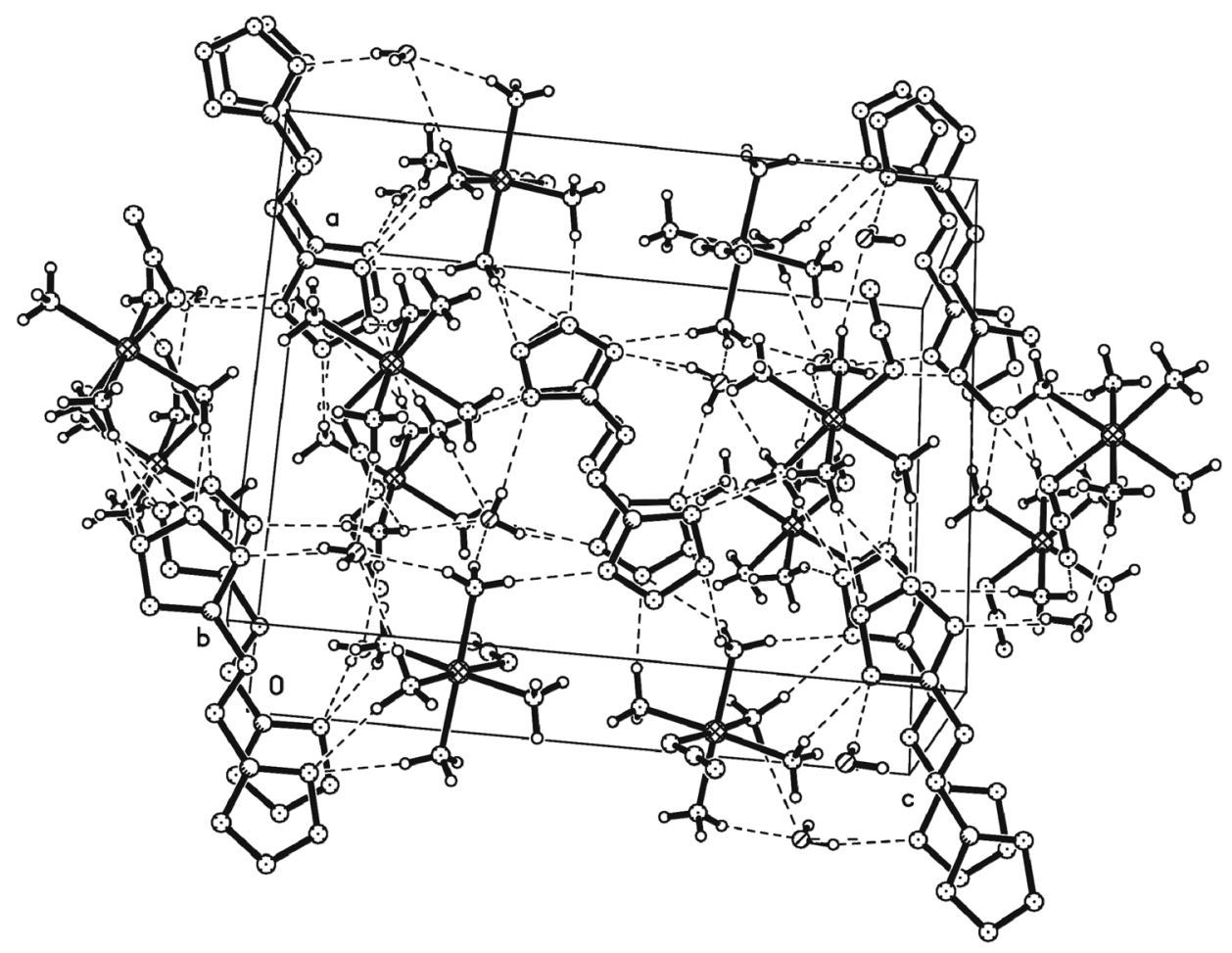

Fig. 12 Packing-diagram of $\left[\mathrm{Co}\left(\mathrm{NH}_{3}\right)_{5} \mathrm{~N}_{3}\right]\left(\mathrm{C}_{2} \mathrm{~N}_{10}\right) \cdot \mathrm{H}_{2} \mathrm{O}(5)$. View along the $b$-axis.

rectangular prismatic crystals in $64 \%$ yield according to Scheme 6.

The IR spectrum of 7 is dominated by strong or medium bands attributable to the asymmetric $\left(1550 \mathrm{~cm}^{-1}(\mathrm{~s})\right)$ and symmetric (1322 $\left.\mathrm{cm}^{-1}(\mathrm{~s})\right)$ stretching vibrations and the deformation vibration $\left(820 \mathrm{~cm}^{-1}(\mathrm{~m})\right)$ of the nitro group. ${ }^{24 a} \mathrm{~A}$ ${ }^{13} \mathrm{C}$ NMR spectrum, measured with a saturated solution in

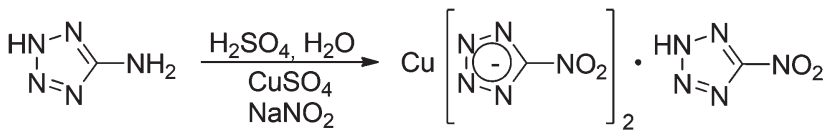

$$
\begin{aligned}
& \mathrm{Cu}(\mathrm{NT})_{2} \cdot \mathrm{HNT}
\end{aligned}
$$

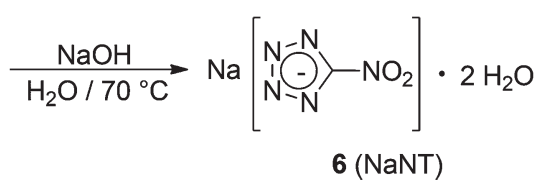

Scheme 5
$\mathrm{D}_{2} \mathrm{O}$, showed the resonance of the single tetrazole ring carbon atom at $\delta 165.2 \mathrm{ppm}$, which differs only slightly from the values around $\delta 169 \mathrm{ppm}$ reported for alkali metal 5-nitrotetrazolates. $^{24 a}$ The formation of trans- $\left[\mathrm{Co}\left(\mathrm{NH}_{3}\right)_{4}\left(\mathrm{NO}_{2}\right)_{2}\right](\mathrm{NT}) \cdot \mathrm{H}_{2} \mathrm{O}$ was also verified by a single-crystal X-ray diffraction study (Table 1, Fig. 13-15). Compound 7 crystallizes in the tetragonal space group $I_{4} \overline{1}$ as the monohydrate.

Similar to the azotetrazolates $\mathbf{2 - 5}$, the individual ions in 7 show no unexpected structural features. With 1.331(3)-1.333(3) $\AA$ all five bonds within the tetrazole ring are identical and comparable to those in other salts comprising the 5-nitrotetrazolate anion. ${ }^{24}$ The nitro group is highly symmetrical with a $\mathrm{N}-\mathrm{O}$ distance of 1.228(2) A. As shown in Fig. 15, the crystal structure of 7 also comprises an extensive network of hydrogen bonds. The crystal structure consists of mutually linked trans-[Co$\left.\left(\mathrm{NH}_{3}\right)_{4}\left(\mathrm{NO}_{2}\right)_{2}\right]^{+}$cations and 5-nitrotetrazolate anions. Details on the hydrogen-bridging can be found in Table S15 in the ESI. N Notably, there are four intramolecular $\mathrm{O} \cdots \mathrm{H}-\mathrm{N}$ hydrogen bonds in the range of 2.901(2)-3.380(2) $\AA$ within the trans-[Co$\left.\left(\mathrm{NH}_{3}\right)_{4}\left(\mathrm{NO}_{2}\right)_{2}\right]^{+}$cation between coordinated $\mathrm{NH}_{3}$ molecules and oxygen atoms of the nitro groups. The water of crystallization

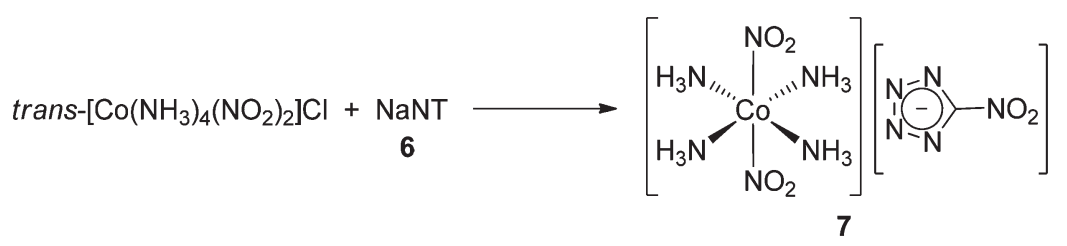




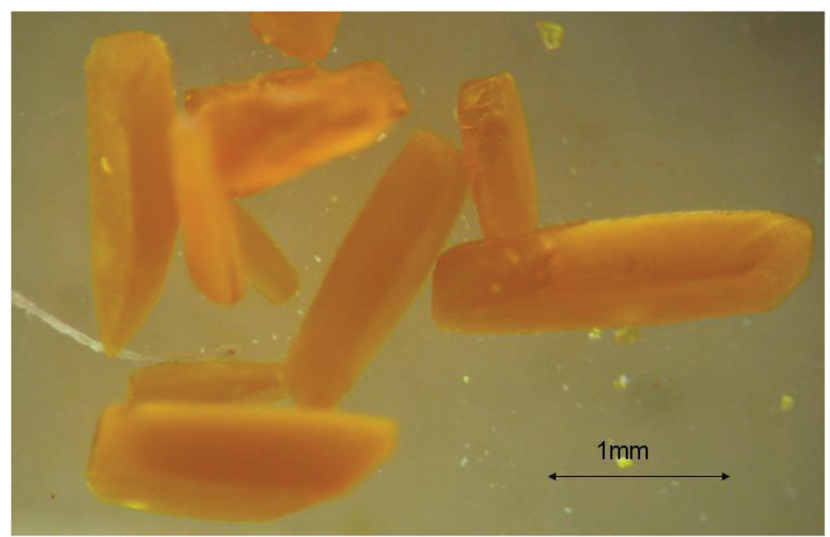

Fig. 13 Single-crystals of trans- $\left[\mathrm{Co}\left(\mathrm{NH}_{3}\right)_{4}\left(\mathrm{NO}_{2}\right)_{2}\right](\mathrm{NT}) \cdot \mathrm{H}_{2} \mathrm{O}(7)$.
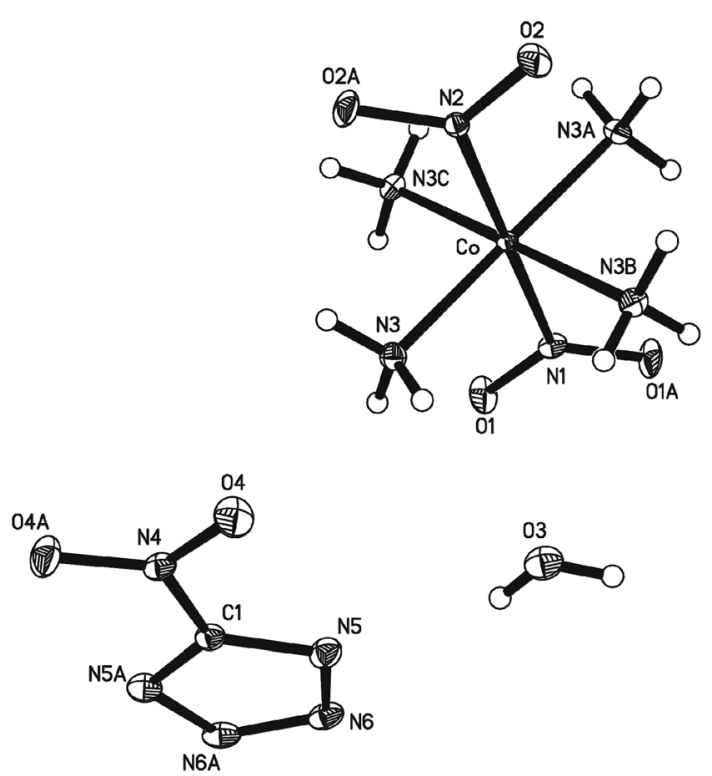

Fig. 14 ORTEP drawing of 7 trans $-\left[\mathrm{Co}\left(\mathrm{NH}_{3}\right)_{4}\left(\mathrm{NO}_{2}\right)_{2}\right](\mathrm{NT}) \cdot \mathrm{H}_{2} \mathrm{O}(7)$ at the $50 \%$ probability level. Selected bond lengths $[\AA]]$ and angles $\left[^{\circ}\right]$ : Co-N(1) 1.937(3), Co-N(2) 1.942(4), Co-N(3) 1.9537(10), Co-N(3)\#2 1.9537(10), Co-N(3)\#3 1.9537(10), Co-N(3)\#4 1.9537(10), C(1)-N(4) 1.438(6), O(4)$\mathrm{N}(4)-\mathrm{C}(1)$ 117.44(16). (\#1 $-x+1,-y+0, z+0$; \#2 -x+0,y+0,z+0; $\# 3 x,-y+1, z ; \# 4-x+0,-y+1, z+0)$.

connects cations and anions via one $\mathrm{N} \cdots \mathrm{H}-\mathrm{O}$ hydrogen bond

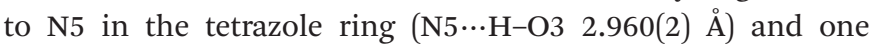
$\mathrm{O} \cdots \mathrm{H}-\mathrm{N}$ hydrogen bond to one of the coordinated $\mathrm{NH}_{3}$ molecules (O3 $\cdots \mathrm{H}-\mathrm{N} 33.082(2) \AA)$. Finally, there is one direct $\mathrm{N} \cdots \mathrm{H}-$ $\mathrm{N}$ hydrogen bond between $\mathrm{N} 6$ in the tetrazole ring and one of

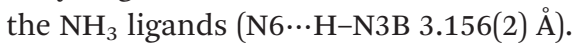

\section{Picrates}

It is well established that anhydrous picric acid tends to be unstable, and its impact and friction sensitivities are higher than those of TNT. Nevertheless, numerous organic and inorganic picrate salts have been prepared and their crystal struc- tures were studied. ${ }^{26}$ Shreeve et al. reported mono and bridged azolium picrates as energetic salts. ${ }^{7 c, 27}$ Picrates of Werner-type cationic cobalt(III) ammine complexes have also been frequently reported, but mainly with respect to studying their solubility and/or crystallinity. A typical example is a publication by Ephraim in which the solubility of various complex cobalt(III) picrates was studied. ${ }^{28}$ These included e.g. [Co$\left.\left(\mathrm{NH}_{3}\right)_{5} \mathrm{H}_{2} \mathrm{O}\right](\text { picrate })_{3},\left[\mathrm{Co}\left(\mathrm{NH}_{3}\right)_{4}\left(\mathrm{H}_{2} \mathrm{O}\right)_{2}\right](\text { picrate })_{3},\left[\mathrm{Co}\left(\mathrm{NH}_{3}\right)_{5} \mathrm{X}\right]-$ (picrate $)_{2}\left(\mathrm{X}=\mathrm{Cl}, \mathrm{Br}, \mathrm{I}, \mathrm{NO}_{2}, \mathrm{NO}_{3}\right)$ as well as cis- and trans-[Co$\left.\left(\mathrm{NH}_{3}\right)_{4}\left(\mathrm{NO}_{2}\right)_{2}\right]$ (picrate). Although the energetic properties of these compounds were not explicitly studied, it was noted that combustion analyses proved difficult due to regularly occurring explosions. ${ }^{28}$ In the course of our study, two Werner-type complex cobalt(III) picrates were prepared as outlined in Scheme 7.

Sodium picrate, prepared in situ by neutralizing picric acid with $\mathrm{NaOH}$, was subsequently treated with either trans-[Co$\left.\left(\mathrm{NH}_{3}\right)_{4}\left(\mathrm{NO}_{2}\right)_{2}\right] \mathrm{Cl}$ or $\left[\mathrm{Co}\left(\mathrm{NH}_{3}\right)_{5} \mathrm{~N}_{3}\right] \mathrm{Cl}_{2}$. The products, trans-[Co$\left.\left(\mathrm{NH}_{3}\right)_{4}\left(\mathrm{NO}_{2}\right)_{2}\right]$ (picrate) $\cdot \mathrm{H}_{2} \mathrm{O}(\mathbf{9})$ and $\left[\mathrm{Co}\left(\mathrm{NH}_{3}\right)_{5} \mathrm{~N}_{3}\right]$ (picrate) $)_{2}(\mathbf{1 0})$, which precipitated from the concentrated aqueous solutions, were isolated by filtration and purified by recrystallization from a minimum amount of hot water. Complex 9 was obtained in 57\% yield as large, orange blocks (Fig. 16), whereas complex $\mathbf{1 0}$ (87\% yield) formed dark red rods (Fig. 19). Complex 9 has already been mentioned in the early work by Ephraim. ${ }^{28}$ Notably, this author described no less than four different crystal forms for this compound, depending on the recrystallization conditions: (1) yellow, hair-like crystals of several centimeters in length; (2) glistening needles and platelets of rhombic shape; and (3) thick, heavy prism-like crystals. As can be seen in Fig. 16, we apparently obtained only the latter sort of crystals. Both the IR and ${ }^{13} \mathrm{C}$ NMR data of 9 and 10 showed the typical values for the picrate anion. Both complexes were also structurally characterized by single-crystal X-ray diffraction (Table 1, Fig. 16-21 and ESI + ).

The dinitro complex $\mathbf{9}$ crystallizes in the triclinic space group $P \overline{1}$. Fig. 17 shows that the unit cell contains two cations, two anions and two water molecules. All bond lengths and angles in the individual components show non-significant deviations from those reported in the literature. ${ }^{21,22}$ Fig. 18 illustrates the supramolecular hydrogen-bonded crystal structure of 9. The two water molecules, the ammine and nitro ligands of the trans- $\left[\mathrm{Co}\left(\mathrm{NH}_{3}\right)_{4}\left(\mathrm{NO}_{2}\right)_{2}\right]^{+}$cation, and the nitro groups of the picrate anion all participate in the complex hydrogen-bonded network. The azido derivative $\mathbf{1 0}$ also crystallizes in the triclinic space group $P \overline{1}$, but has no water of crystallization. As can be seen in Fig. 21, all ligands in the [Co$\left.\left(\mathrm{NH}_{3}\right)_{5} \mathrm{~N}_{3}\right]^{2+}$ dication as well as the oxygen atoms of the phenoxide and nitro groups of the picrate anions participate in the $\mathrm{N}-\mathrm{H} \cdots \mathrm{O}$ and $\mathrm{N}-\mathrm{H} \cdots \mathrm{N}$ hydrogen bonds forming the supramolecular network (see ESI + for full details).

\section{Dipicrylamides}

Dipicrylamine $\left(2,2^{\prime}, 4,4^{\prime}, 6,6^{\prime}\right.$-hexanitrodiphenylamine, Scheme 8) combines several interesting structural features in that it contains six nitro groups which are flexible and can interact and 


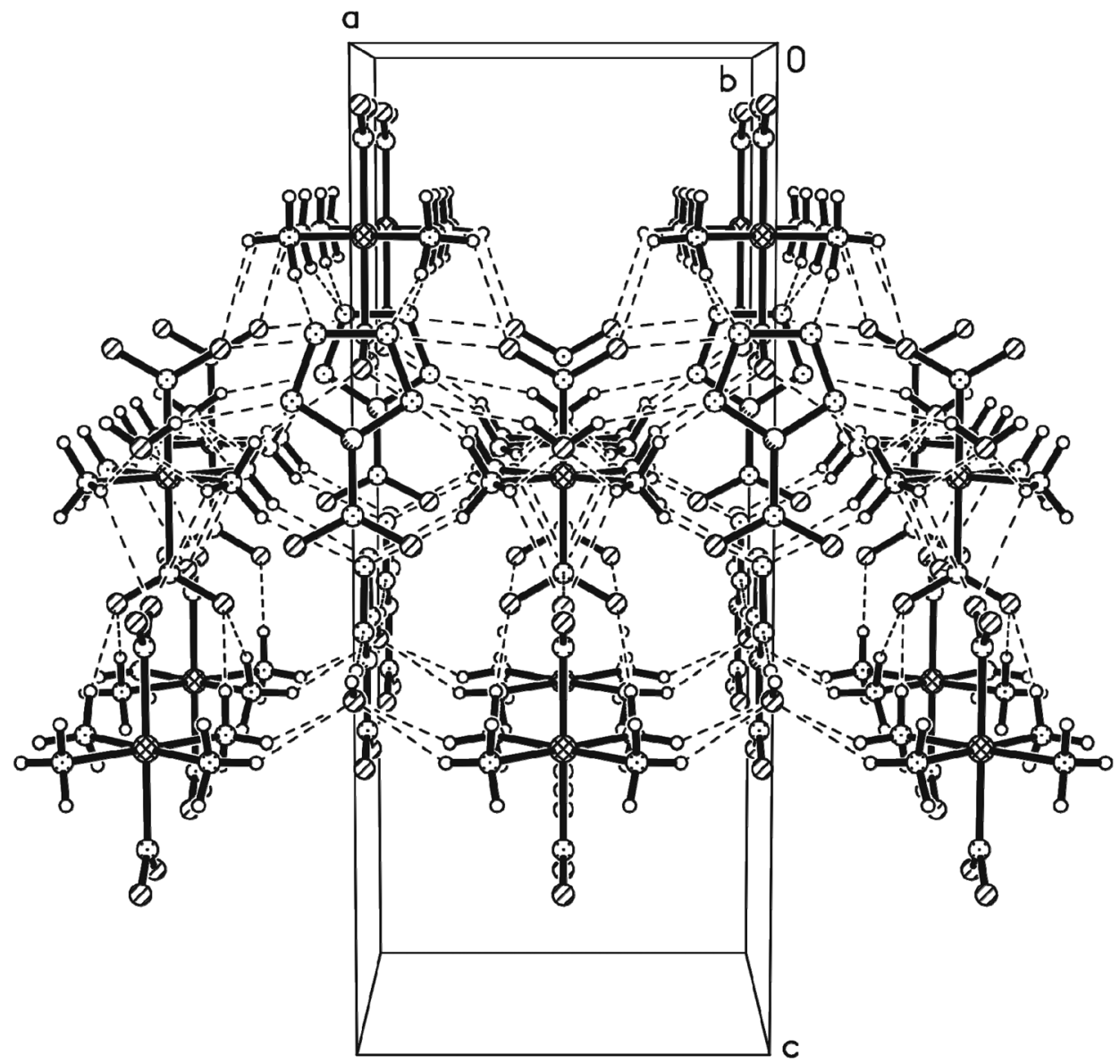

Fig. 15 Packing diagram of trans- $\left[\mathrm{Co}\left(\mathrm{NH}_{3}\right)_{4}\left(\mathrm{NO}_{2}\right)_{2}\right](\mathrm{NT}) \cdot \mathrm{H}_{2} \mathrm{O}(7)$. View along the $b$-axis.

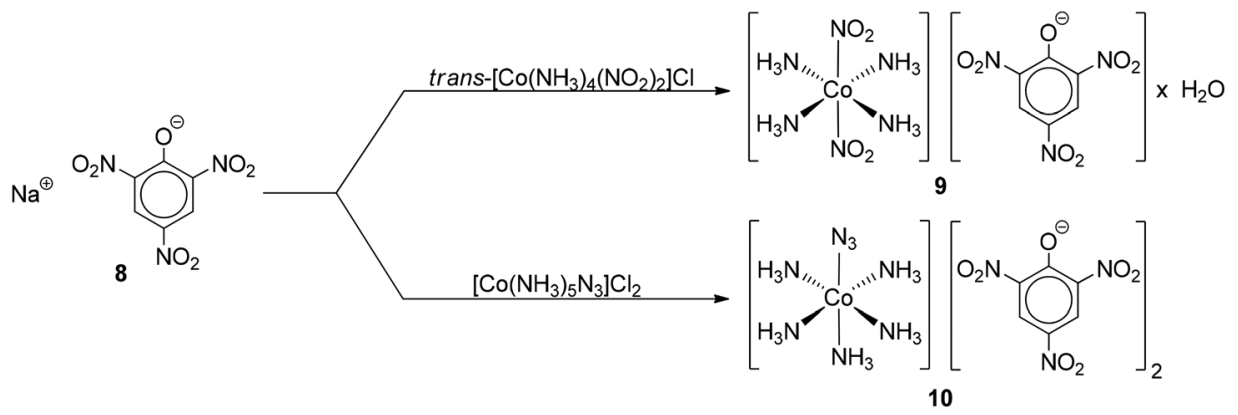

Scheme 7

adjust in the crystal lattice and in that it has a secondary amine group which can be deprotonated with alkali and alkaline earth metal hydroxides to form water soluble salts. In the resulting dipicrylamide anion $\left(=\mathrm{DPA}^{-}\right)$, partial delocalization of the negative charge mediated by the aromatic rings is possible, which may facilitate coordination of the oxygen atoms of the nitro groups with suitable metal ions. ${ }^{29}$

The ammonium salt of dipicrylamine, also known as Aurantia or Imperial Yellow, was discovered in 1874 by Gnehm and used as a yellow colorant for leather, wool, and silk until the early 20th century. ${ }^{30}$ However, this use has been terminated due to the highly toxic and explosive nature of dipicrylamine. ${ }^{31}$ Dipicrylamine can also be used for the extraction of $\mathrm{K}^{+}$ions from sea bittern (a mixture of $\mathrm{K}^{+}, \mathrm{Na}^{+}$, and $\mathrm{Mg}^{2+}$ ). ${ }^{32 a}$ A related study carried out with a mixture of $\mathrm{K}^{+}, \mathrm{Rb}^{+}$, and $\mathrm{Cs}^{+}$revealed that the $\mathrm{Cs}^{+}$ion shows maximum selectivity towards $\mathrm{DPA}^{-} \cdot{ }^{32 b}$ In fact, it has been reported that $\mathrm{DPA}^{-}$can be used for the recovery of $\mathrm{Cs}^{+}$from radioactive wastes. ${ }^{33}$ Only recently, the structural chemistry of alkali metals and alkaline earth metals as well as ammonium and azolium dipicrylamides has been 


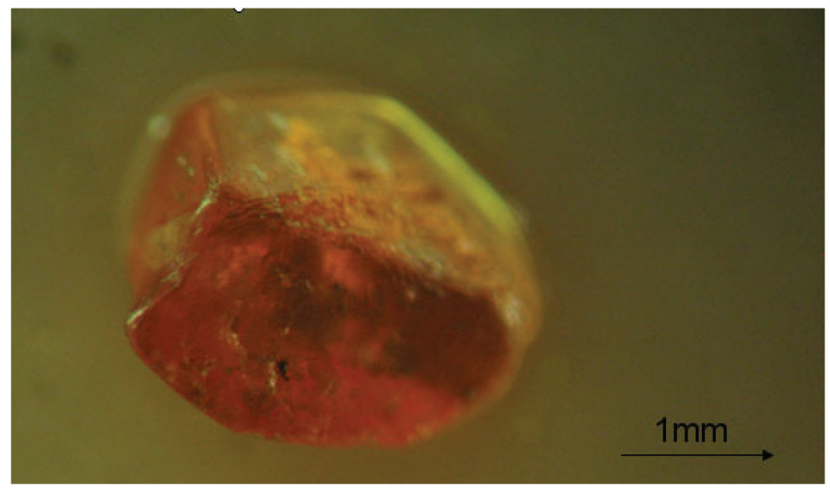

Fig. 16 Single-crystal of trans- $\left[\mathrm{Co}\left(\mathrm{NH}_{3}\right)_{4}\left(\mathrm{NO}_{2}\right)_{2}\right]($ picrate) $) \cdot \mathrm{H}_{2} \mathrm{O}(9)$.

investigated in detail. All these compounds display interesting hydrogen-bonded supramolecular structures in the solid state. $^{29}$

A Werner-type cobalt(III)-ammine complex of dipicrylamide was prepared according to Scheme 9 by treatment of trans-[Co$\left.\left(\mathrm{NH}_{3}\right)_{4}\left(\mathrm{NO}_{2}\right)_{2}\right] \mathrm{Cl}$ with 1 equiv. of in situ-prepared NaDPA (Scheme 9).

Compound 12 was isolated in 53\% yield in the form of orange, somewhat irregular blocks (Fig. 22). Both the IR spectrum and elemental analysis indicated the formation of a hydrated species. An X-ray structural analysis confirmed the presence of the monohydrate trans $-\left[\mathrm{Co}\left(\mathrm{NH}_{3}\right)_{4}\left(\mathrm{NO}_{2}\right)_{2}\right](\mathrm{DPA}) \cdot \mathrm{H}_{2} \mathrm{O}$ (12) (Table 1, Fig. 22-24).

Complex 12 crystallizes in the triclinic space group $P \overline{1}$. Fig. 23 shows that the unit cell contains two crystallographically independent trans- $\left[\mathrm{Co}\left(\mathrm{NH}_{3}\right)_{4}\left(\mathrm{NO}_{2}\right)_{2}\right]^{+}$cations and two DPA anions. The structural parameters (bond lengths and angles) in the dipicrylamide anions show only little differences when compared to those reported for the alkali, alkaline earth metals, ammonium or azolium salts of dipicrylamide. ${ }^{29}$
The non-electrolyte complex $\operatorname{mer}-\left[\mathrm{Co}(\mathrm{en})(\mathrm{py})\left(\mathrm{N}_{3}\right)_{3}\right](13)$

Well known from the early studies on Werner-type cobalt(III) azido complexes is the non-electrolyte complex mer-[Co$\left.\left(\mathrm{NH}_{3}\right)_{3}\left(\mathrm{~N}_{3}\right)_{3}\right]$. The highly explosive material was first reported by Linhard and Weigel in $1950 .{ }^{18}$ This dark blue-green compound was found to form in various occasions when aquo- or azido-cobalt(III) ammine complexes are treated with excess sodium azide. The best synthetic method ( $94 \%$ yield) involves the reaction of $\left[\mathrm{Co}\left(\mathrm{NH}_{3}\right)_{4}\left(\mathrm{H}_{2} \mathrm{O}\right)_{2}\right]\left(\mathrm{ClO}_{4}\right)_{3}$ with a large excess of $\mathrm{NaN}_{3}$. Almost quantitative yields of mer-[Co$\left.\left(\mathrm{NH}_{3}\right)_{3}\left(\mathrm{~N}_{3}\right)_{3}\right]$ can also be obtained in a simple manner by airoxidation of a mixture of $\mathrm{CoSO}_{4} \cdot 7 \mathrm{H}_{2} \mathrm{O},\left(\mathrm{NH}_{4}\right)_{2} \mathrm{SO}_{4}$ and $\mathrm{NaN}_{3}$ in aqueous ammonia solution. It was noted that even small amounts of mer-[Co( $\left.\left(\mathrm{NH}_{3}\right)_{3}\left(\mathrm{~N}_{3}\right)_{3}\right]$ could lead to dangerous detonations upon heating grinding or impact. Detonations were even observed when larger crystals were ground under water. ${ }^{18}$ We now succeeded in the preparation and structural characterization of a new non-electrolyte complex formally derived from cobalt(III) triazide. To an aqueous solution of [Co(en)(py) $\left.{ }_{2}\left(\mathrm{NH}_{3}\right) \mathrm{Cl}\right] \mathrm{Cl}_{2} \cdot \mathrm{H}_{2} \mathrm{O}^{34}$ was added a ca. 20-fold excess of $\mathrm{NaN}_{3}$ and the reaction mixture was heated on a steam bath until all the water had evaporated. During the reaction a color change from red to dark green occurred and the smell of pyridine became evident. Unreacted sodium azide was easily removed by repeated washing of the dark residue with cold water. After drying in air, the new non-electrolyte complex mer-[Co(en)(py)$\left.\left(\mathrm{N}_{3}\right)_{3}\right]$ (13) was isolated in 93\% yield as a dark blue-green crystalline solid (Scheme 10). As expected for a non-electrolyte complex, the solubility of $\mathbf{1 3}$ in water is very low, although the resulting very dilute solutions show an intense dark green color.

This material was found to be unpredictably and dangerously explosive. It should thus be prepared and handled only in very small amounts and with utmost care. Compound 13

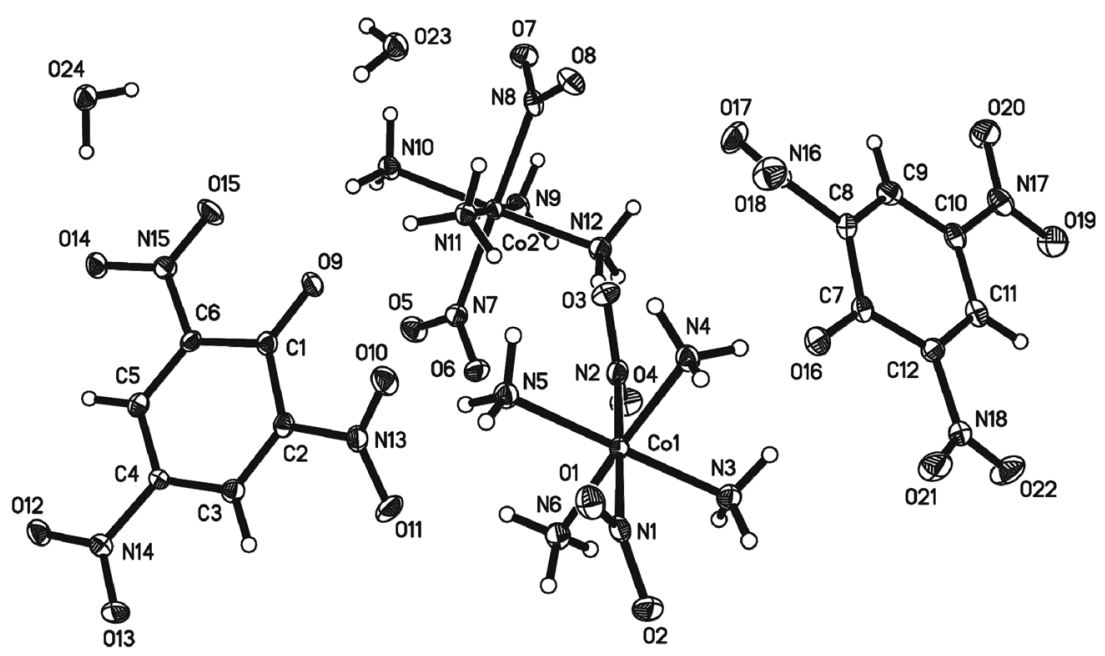

Fig. 17 ORTEP drawing of trans- $\left[\mathrm{Co}\left(\mathrm{NH}_{3}\right)_{4}\left(\mathrm{NO}_{2}\right)_{2}\right]\left(\right.$ picrate) $\cdot \mathrm{H}_{2} \mathrm{O}(9)$ at the $50 \%$ probability level. Selected bond lengths [Å] and angles [ $\left.{ }^{\circ}\right]$ : $\mathrm{Co}(1)-\mathrm{N}(2)$ 1.931(3), Co(1)-N(1) 1.943(3), Co(1)-N(3) 1.956(3), Co(1)-N(4) 1.962(3), Co(1)-N(6) 1.965(3), Co(1)-N(5) 1.967(3), Co(2)-N(8) 1.936(3), Co(2)-N(7) $1.942(3), \mathrm{Co}(2)-\mathrm{N}(12) 1.958(3), \mathrm{Co}(2)-\mathrm{N}(11) 1.959(3), \mathrm{Co}(2)-\mathrm{N}(10) 1.968(3), \mathrm{Co}(2)-\mathrm{N}(9) 1.973(3), \mathrm{N}(2)-\mathrm{Co}(1)-\mathrm{N}(1) 179.39(13), \mathrm{N}(8)-\mathrm{Co}(2)-\mathrm{N}(7) 179.05(13)$. 


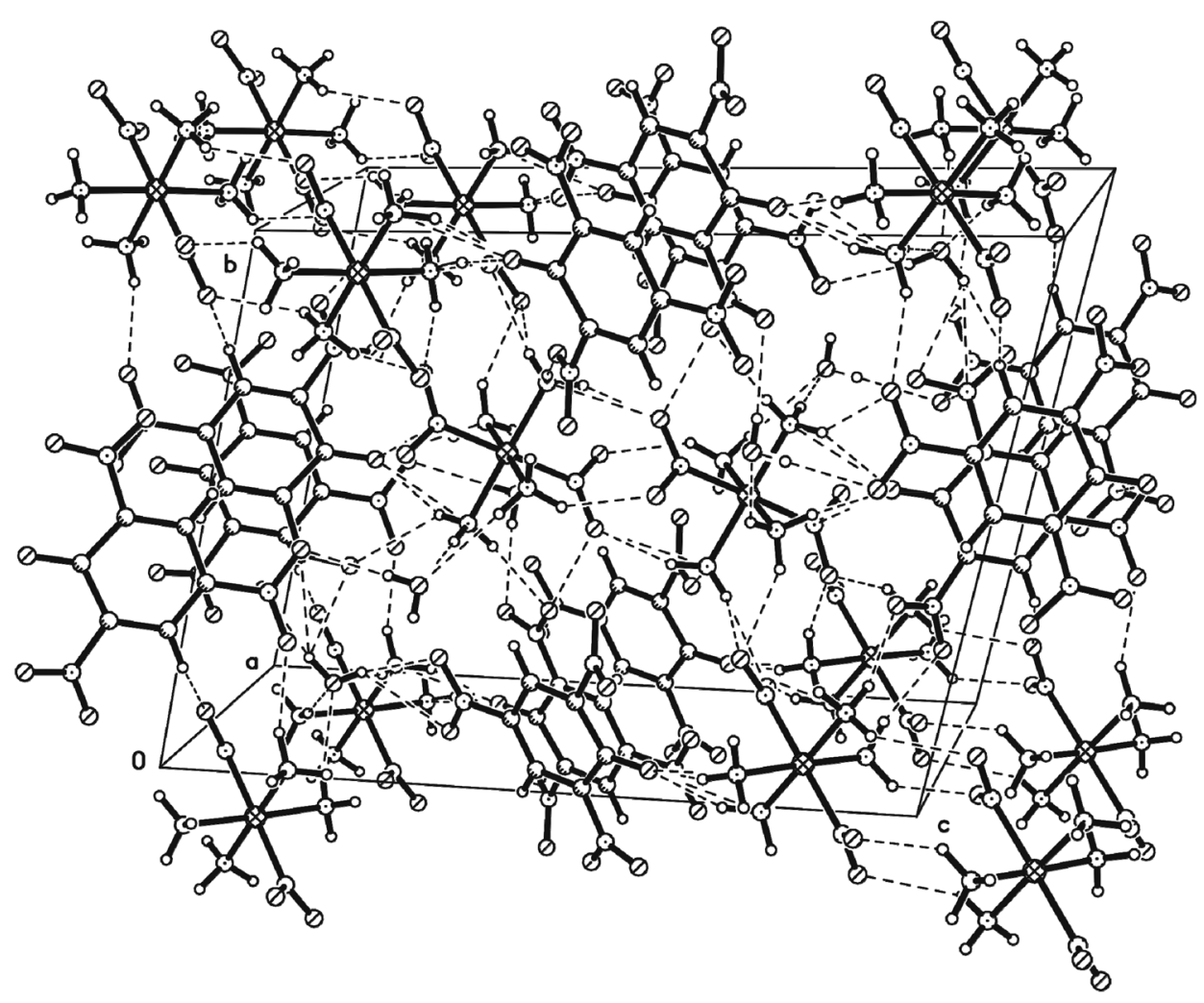

Fig. 18 Packing diagram of trans- $\left[\mathrm{Co}\left(\mathrm{NH}_{3}\right)_{4}\left(\mathrm{NO}_{2}\right)_{2}\right]($ picrate $) \cdot \mathrm{H}_{2} \mathrm{O}(9)$. View along the a-axis.

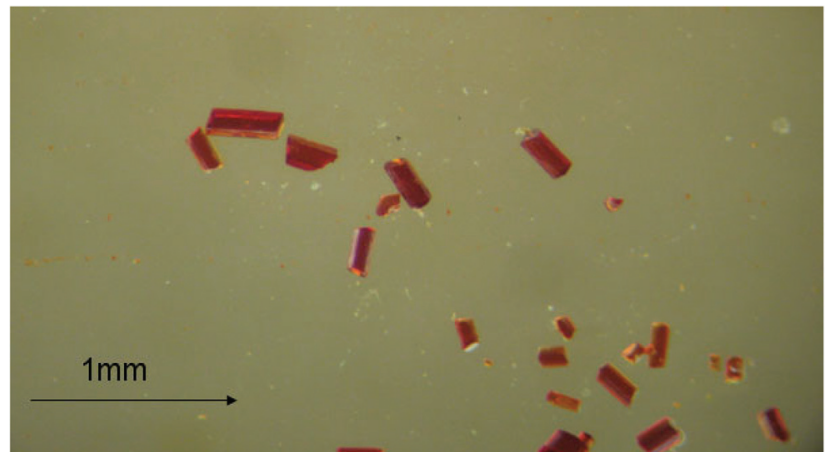

Fig. 19 Single-crystals of $\left[\mathrm{Co}\left(\mathrm{NH}_{3}\right)_{5} \mathrm{~N}_{3}\right](\text { picrate })_{2}(10)$.

was even too dangerously explosive to be fully characterized by IR and elemental analysis. Attempts to obtain an IR spectrum of 13 were unsuccessful, because an explosion occurred upon grinding of $c a .2-3 \mathrm{mg}$ with $c a .100 \mathrm{mg}$ of $\mathrm{KBr}$. As a derivative of the unknown cobalt triazide, compound 13 has a high nitrogen content of $c a$. $52 \%$ which certainly accounts for its highly explosive nature. Despite all the dangerous properties, it proved possible to structurally verify the nature of $\mathbf{1 3}$ by singlecrystal X-ray diffraction. Even this task was met by major obstacles. Recrystallization from hot water was impossible due to the low solubility of $\mathbf{1 3}$. Thus small portions of the originally obtained material were spread on glass sample holders and searched under a microscope for suitable crystals. It turned out that most of the crystals were strongly intergrown, with most of them having the appearance of Christmas trees. Notably, like mer-[Co( $\left.\left(\mathrm{NH}_{3}\right)_{3}\left(\mathrm{~N}_{3}\right)_{3}\right],{ }^{18}$ the crystals of 13 were blue-green dichroitic. Finally, a small blue-green crystal fragment was found to be suitable for X-ray diffraction (Table 1 and Fig. 25 and 26; see also ESI\$). As shown in Fig. 25, the three azide ligands in $\mathbf{1 3}$ are arranged in meridional positions as in the parent non-electrolyte mer- $\left[\mathrm{Co}\left(\mathrm{NH}_{3}\right)_{3}\left(\mathrm{~N}_{3}\right)_{3}\right]{ }^{18}$ The Co-N bond lengths to the two opposing azide ligands are iden-

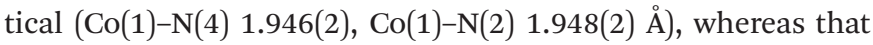
to the azide ligands trans to an amino group of ethylenediamine is slightly longer $(\mathrm{Co}(1)-\mathrm{N}(7)$ 1.962(2) $\AA$ ). The packing diagram of 13 shows a polymeric hydrogen-bonded network (Fig. 26). In this case, supramolecular association of the complex molecules occurs only via $\mathrm{N} \cdots \mathrm{H}-\mathrm{N}$ hydrogen bonds between terminal azide nitrogen atoms and the $\mathrm{NH}_{2}$ groups of the coordinated ethylenediamine.

\section{Energetic properties of the new cobalt(III) complexes}

The methods for testing primary explosives have just been summarized in a very informative short review article by Mehta et al. $^{35}$ In addition to a simple combustion test, the impact and friction sensitivity were tested according to established BAM methods using a BAM drophammer and BAM friction tester (Fig. 27 and 28). ${ }^{1 c}$ The initial test results of the energetic properties of seven cobalt(III) complexes prepared in the course of this study are listed in Table 2. Not included in the table is the dipicrylamide derivative $\mathbf{1 2}$ because it was found to be insensitive to both impact and friction. Also not 

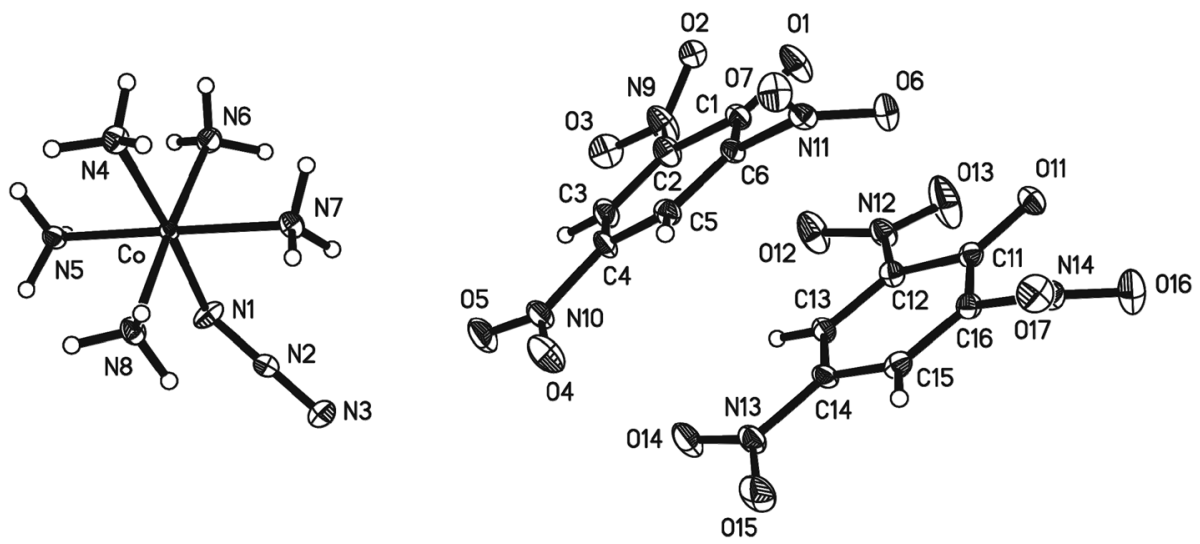

Fig. 20 ORTEP drawing of $\left[\mathrm{Co}\left(\mathrm{NH}_{3}\right)_{5} \mathrm{~N}_{3}\right](\text { picrate })_{2}(10)$ at the $50 \%$ probability level. Selected bond lengths $[\AA \AA]$ and angles [ $\left.{ }^{\circ}\right]$ : Co-N(5) $1.945(2)$, Co-N(1) 1.950(3), Co-N(8) 1.961(2), Co-N(4) 1.967(2), Co-N(6) 1.975(2), Co-N(7) 1.980(2), N(1)-Co-N(4) 175.08(9).

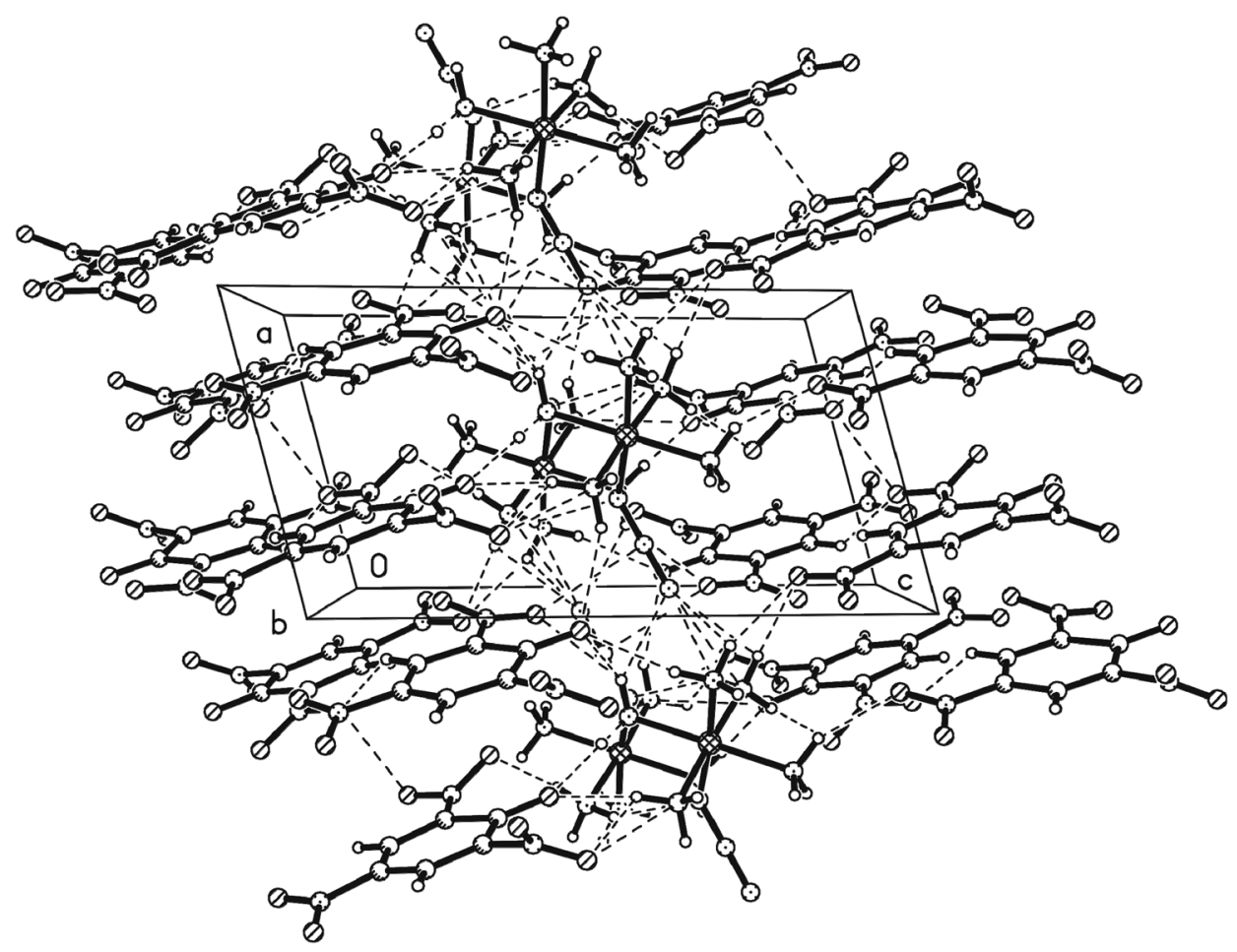

Fig. 21 Packing diagram of $\left[\mathrm{Co}\left(\mathrm{NH}_{3}\right)_{5} \mathrm{~N}_{3}\right](\text { picrate })_{2}(10)$. View along the $b$-axis.<smiles>O=[N+]([O-])c1cc([N+](=O)[O-])c(Nc2c([N+](=O)[O-])cc([N+](=O)[O-])cc2[N+](=O)[O-])c([N+](=O)[O-])c1</smiles>

Scheme 8

included is the non-electrolyte complex $\operatorname{mer}-\left[\mathrm{Co}(\mathrm{en})(\mathrm{py})\left(\mathrm{N}_{3}\right)_{3}\right]$ (13). This complex was found to be too sensitive to be handled safely. All tests were repeated six times over a storage period of 30 days. These test series revealed no significant deviations from the originally measured values, indicating a good long- term stability of the title compounds. Moreover, the drophammer tests were repeated in the temperature range of $-55{ }^{\circ} \mathrm{C}$ to $20^{\circ} \mathrm{C}$ in order to get an impression of the low-temperature performance. For example, hunting and sports ammunition is expected to show good performance at temperatures down to $-25{ }^{\circ} \mathrm{C}$, whereas military ammunition should function even at temperatures as low as $-55^{\circ} \mathrm{C}$. Thus, drophammer tests of all seven compounds were performed at $-55{ }^{\circ} \mathrm{C},-30{ }^{\circ} \mathrm{C}, 0{ }^{\circ} \mathrm{C}$, $10{ }^{\circ} \mathrm{C}$, and $20^{\circ} \mathrm{C}$. In all cases these tests revealed an unexpected increase of the impact sensitivity by $1-2 \mathrm{~J}$ at temperatures below $0{ }^{\circ} \mathrm{C}$ which remained constant to $-55{ }^{\circ} \mathrm{C}$. Although this effect may be small, it is significant and repro- 


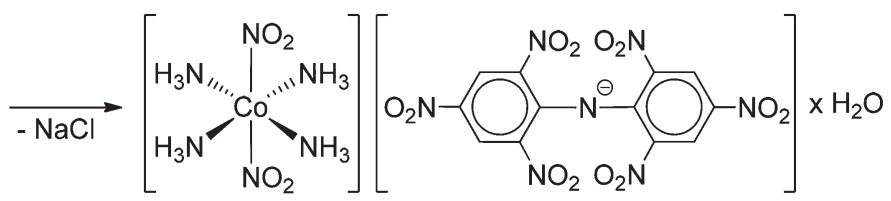

12

Scheme 9

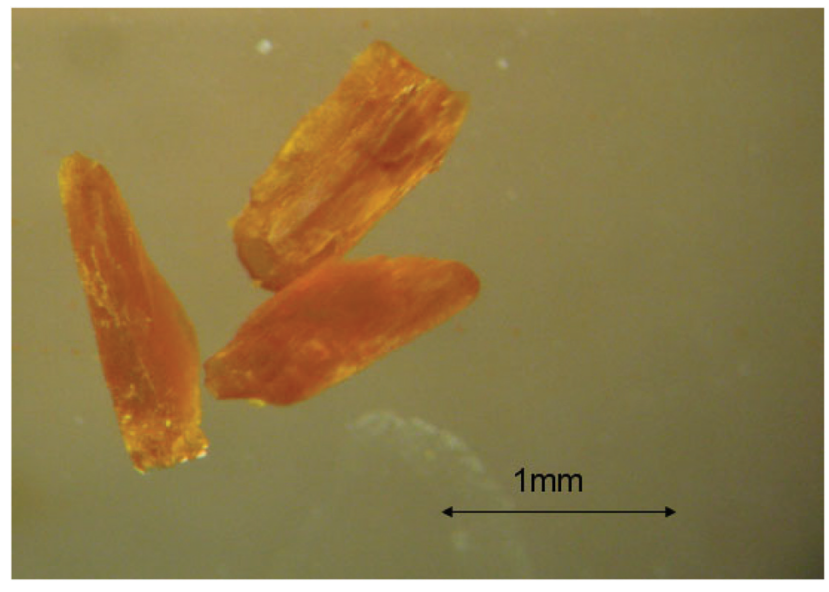

Fig. 22 Single-crystals of trans- $\left[\mathrm{Co}\left(\mathrm{NH}_{3}\right)_{4}\left(\mathrm{NO}_{2}\right)_{2}\right](\mathrm{DPA}) \cdot \mathrm{H}_{2} \mathrm{O}(12)$. ducible. In summary, all energetic cobalt(III) complexes showed a stable performance over the entire temperature range of 75 degrees.

As shown in Table 2, all four azotetrazolates were found to be impact-sensitive. For the azido complex 5, the drophammer test revealed that this compound is very sensitive to impact. The value of 3.5-5 J for 5 is comparable to those found for $\mathrm{Pb}\left(\mathrm{N}_{3}\right)_{2}(3.0-6.5 \mathrm{~J})$ or lead(II) styphnate $(2.5-5.0 \mathrm{~J}){ }^{1 b}$ so that 5 can be classified as a primary explosive. This is not surprising in view of the fact that $\mathbf{5}$ has the highest nitrogen content (68.47\%) of all compounds studied. In contrast, all four compounds showed only low sensitivity to friction, with compound 3 being more or less insensitive. Three of the samples $(\mathbf{3}, \mathbf{4}$, and 5) exploded upon ignition with a flame, while a sample of compound 2 showed only deflagration.

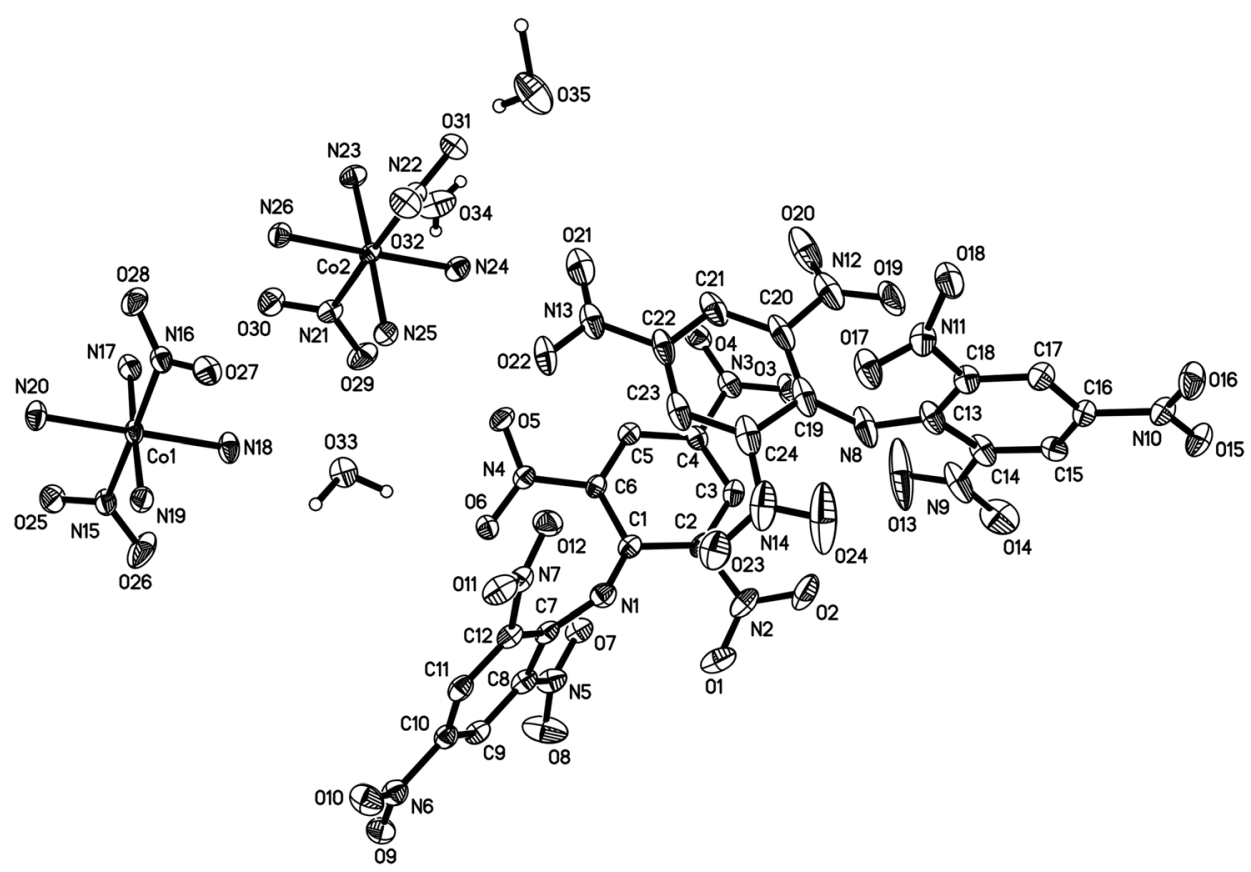

Fig. 23 ORTEP drawing of trans-[Co( $\left.\left(\mathrm{NH}_{3}\right)_{4}\left(\mathrm{NO}_{2}\right)_{2}\right](\mathrm{DPA}) \cdot \mathrm{H}_{2} \mathrm{O}(12)$ at the $50 \%$ probability level. Selected bond lengths [Å] and angles [ $\left.{ }^{\circ}\right]$ : $\mathrm{Co}(1)-\mathrm{N}(16)$ 1.9298(18), Co(1)-N(15) 1.9353(18), Co(1)-N(19) 1.953(2), Co(1)-N(20) 1.9543(17), Co(1)-N(17) 1.9607(19), Co(1)-N(18) 1.9616(18), Co(2)-N(22) 1.9325(17), $\mathrm{Co}(2)-\mathrm{N}(24)$ 1.9416(18), Co(2)-N(21) 1.9425(18), Co(2)-N(26) 1.9534(17), Co(2)-N(23) 1.9545(17), Co(2)-N(25) 1.9575(17), C(1)-N(1) 1.292(3), C(7)$\mathrm{N}(1) 1.312(3), \mathrm{C}(13)-\mathrm{N}(8) 1.295(3), \mathrm{C}(19)-\mathrm{N}(8) 1.314(3), \mathrm{C}(1)-\mathrm{N}(1)-\mathrm{C}(7) 144.45(19), \mathrm{C}(13)-\mathrm{N}(8)-\mathrm{C}(19) 140.8(2)$. 


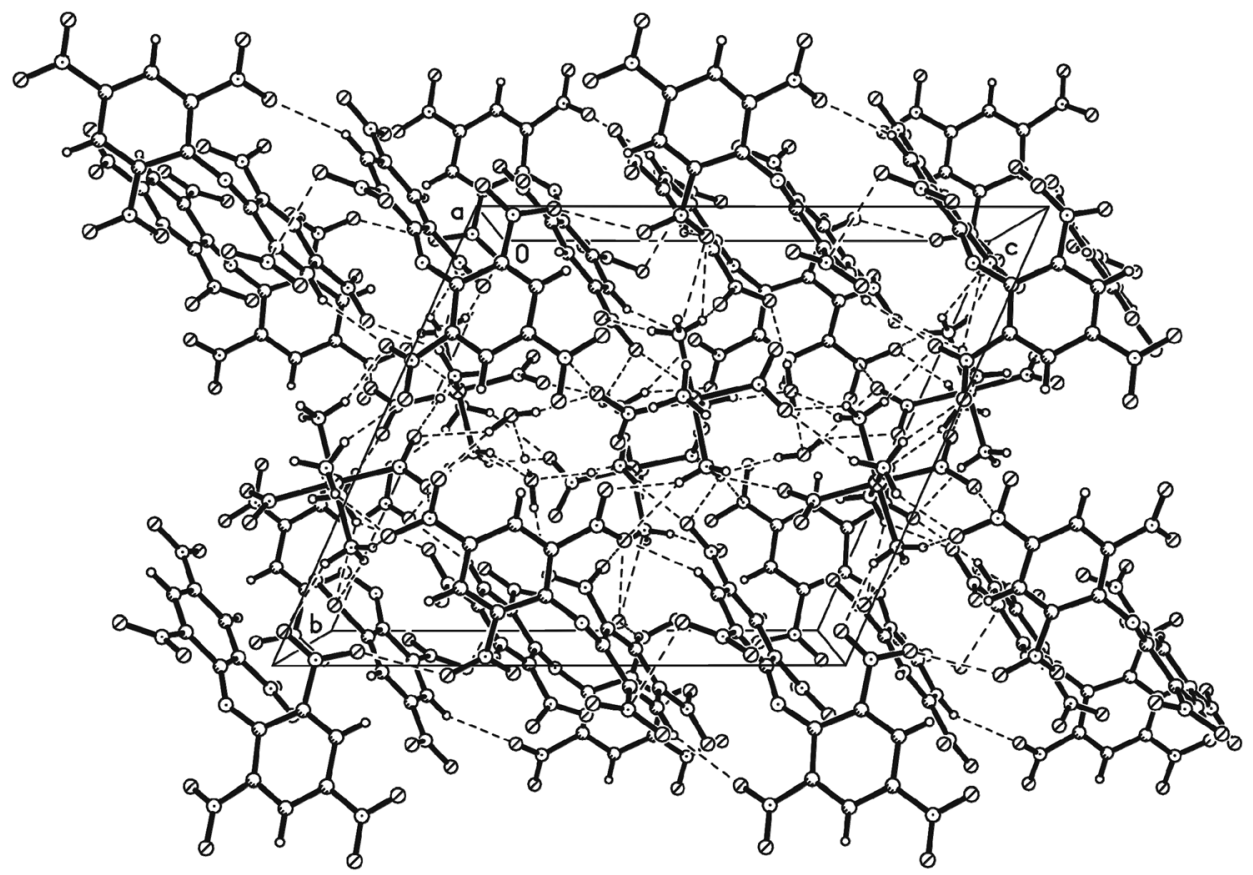

Fig. 24 Packing diagram of trans $-\left[\mathrm{Co}\left(\mathrm{NH}_{3}\right)_{4}\left(\mathrm{NO}_{2}\right)_{2}\right](\mathrm{DPA}) \cdot \mathrm{H}_{2} \mathrm{O}(12)$. View along the a-axis.

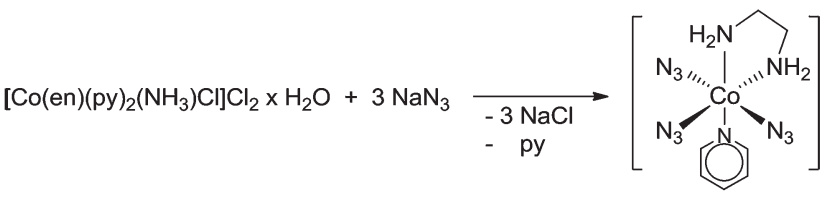

13

Scheme 10

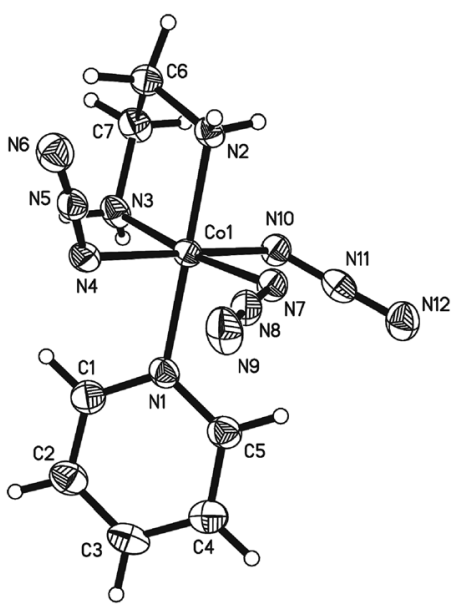

Fig. 25 ORTEP drawing of [Co(en)(py) $\left.\left(\mathrm{N}_{3}\right)_{3}\right](13)$ at the $50 \%$ probability level. Selected bond lengths $[\AA \AA]$ and angles $\left[^{\circ}\right]$ : $\mathrm{Co}(1)-N(4)$ 1.946(2), $\mathrm{Co}(1)-\mathrm{N}(2)$ 1.948(2), $\mathrm{Co}(1)-\mathrm{N}(7)$ 1.962(2), Co(1) $-\mathrm{N}(10)$ 1.969(2), Co(1)$\mathrm{N}(3)$ 1.973(2), Co(1)-N(1) 1.975(2), N(2)-Co(1)-N(1) 179.39(10), N(4)Co(1)-N(10) 174.59(10).
The values for the 5-nitrotetrazolate complex 7 show that with a low value of $5 \mathrm{~J}$ the impact sensitivity of this compound is comparable to that of lead(II) azide. Thus this compound can also be classified as a primary explosive. This, combined with a good oxygen balance $\Omega$ of $-13.67 \%$ and a relatively high nitrogen content of $\sim 44 \%$ makes compound 7 a promising candidate for further testing. In the flame test, a sample of complex 7 showed deflagration.

Both picrates $\mathbf{9}$ and $\mathbf{1 0}$ can also be classified as primary explosives. With values of 8 (9) and 7.5 (10) they are slightly less sensitive to impact than lead(II) styphnate or lead(II) azide and at the same time much less friction-sensitive. However, both samples exploded upon ignition with a flame. With $27.10 \%$ (9) and $30.53 \%$ (10) the nitrogen content is still quite good, while the negative oxygen balance can be explained by the high carbon content of these picrates. In view of the easy accessibility of these and related complexes, such Werner-type cobalt(III) picrates certainly merit further investigation as alternative energetic materials. As mentioned above, the dipicrylamide complex $\mathbf{1 2}$ was found to be insensitive to both impact and friction ( $>40 \mathrm{~J}$ and $>360 \mathrm{~N}$, resp.). This is in agreement with recent findings by Zhou et al. who reported that the impact sensitivities of various ammonium and azolium dipicrylamides are in the range of that of the secondary explosive TNT. $^{29 c}$ In view of the known high toxicity of dipicrylamine, ${ }^{29 c, 30}$ this energetic anion does not appear to be a useful alternative for lead(II)-containing explosives anyway. In contrast, the non-electrolyte complex 13 could not be safely tested as even minor samples of $2-3 \mathrm{mg}$ could explode in an unpredictable manner. 


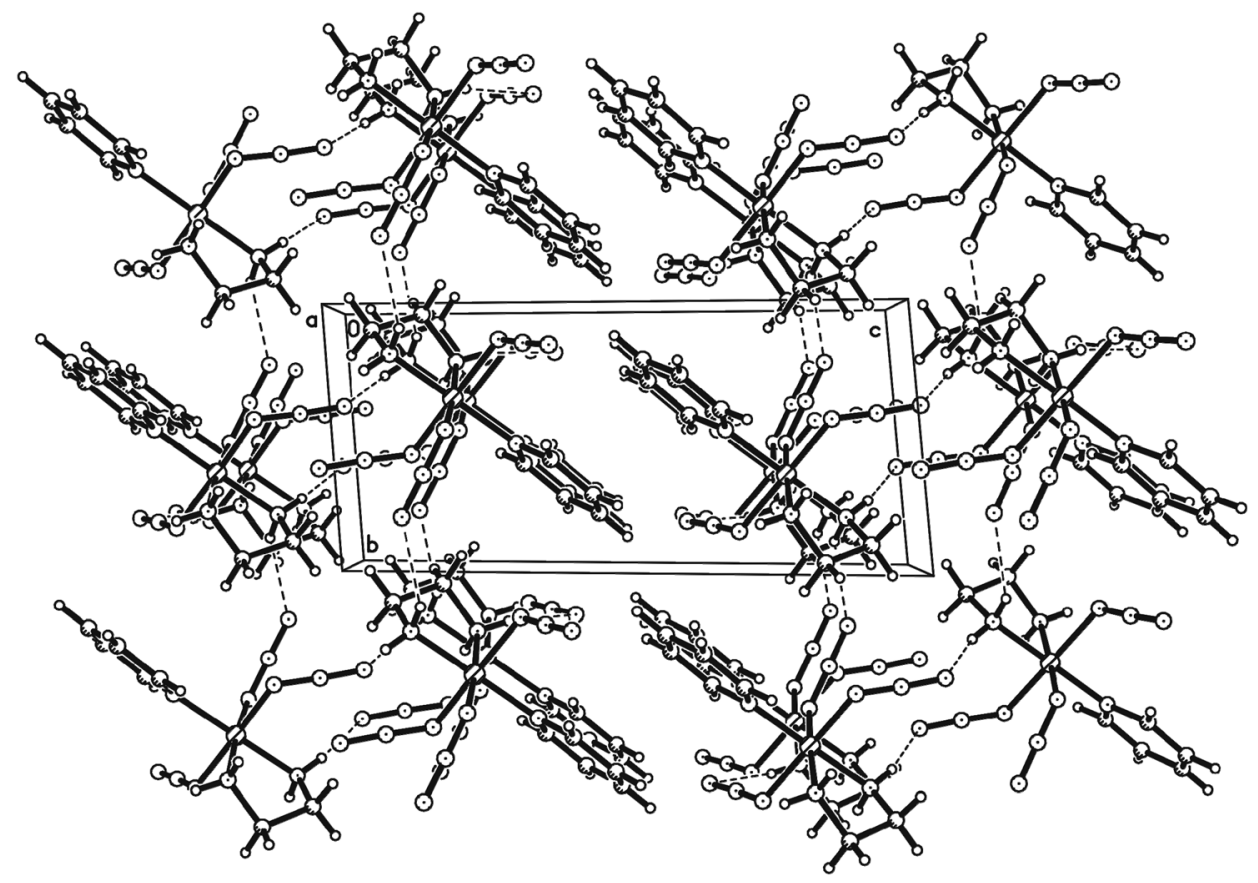

Fig. 26 Packing diagram of $\left[\mathrm{Co}(\mathrm{en})(\mathrm{py})\left(\mathrm{N}_{3}\right)_{3}\right](13)$. View along the a-axis.

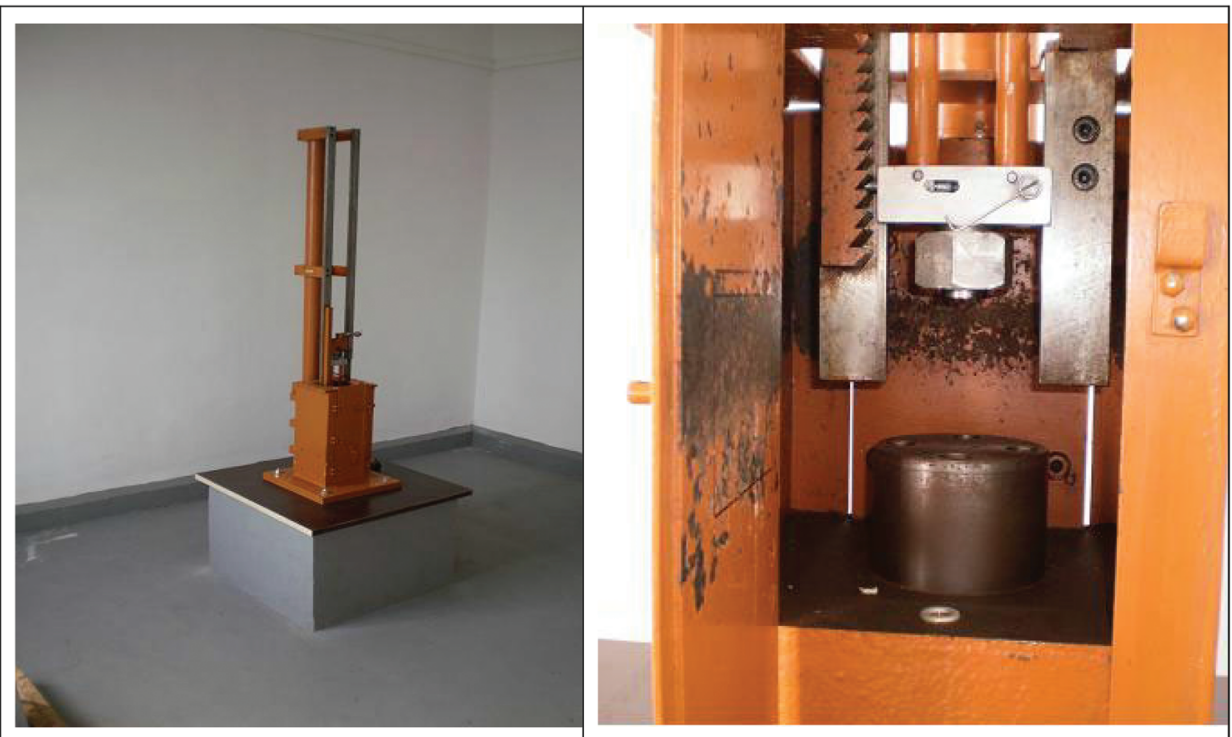

Fig. 27 BAM drophammer setup used in this study.

\section{Conclusions}

In summarizing the work reported here, we have investigated the synthesis, structures, and energetic properties of a series of novel Werner-type cobalt(III) ammine complexes comprising the energetic anions azotetrazolate, nitrotetrazolate, picrate and dipicrylamide in the outer sphere, i.e. not directly coordinated to the central $\mathrm{Co}^{3+}$ ion. The title compounds are accessible in a straightforward manner by simple salt metathesis reactions using readily available starting materials. Also easily prepared, though unpredictably and dangerously explosive, is the new dark blue-green non-electrolyte complex mer-[Co(en)(py) $\left.\left(\mathrm{N}_{3}\right)_{3}\right]$ (13). The crystal structures of all new complexes are characterized by extensive hydrogen-bonded networks. In addition to the structural authentication by X-ray diffraction, the energetic properties of these explosive Wernertype cobalt(III) complexes have been tested. The tests revealed that several of the title complexes can be classified as primary explosives. Particularly promising in that respect are the compounds 5 and $\mathbf{1 0}$ which contain the $\left[\mathrm{Co}\left(\mathrm{NH}_{3}\right)_{5} \mathrm{~N}_{3}\right]^{+}$cation, as 


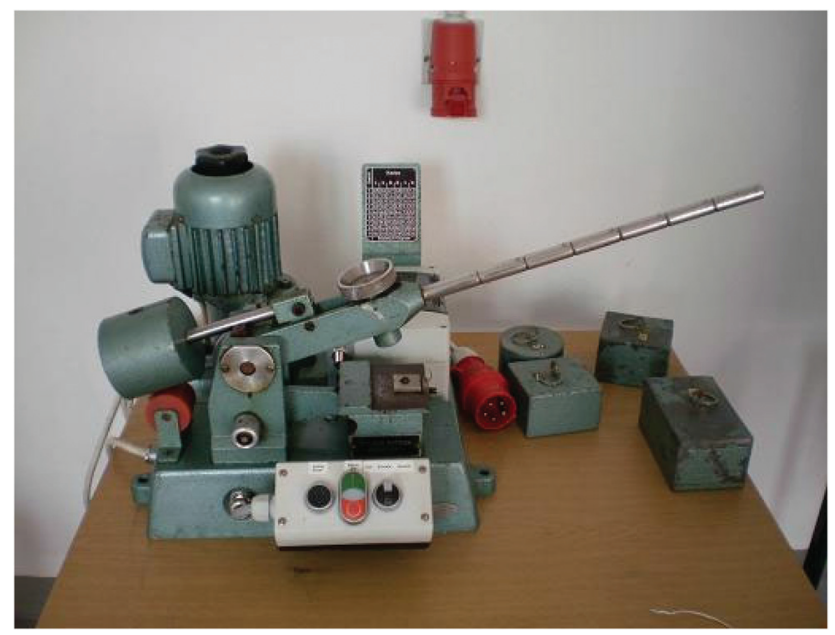

Fig. 28 BAM friction test setup used in this study.

well as the nitrotetrazolate trans- $\left[\mathrm{Co}\left(\mathrm{NH}_{3}\right)_{4}\left(\mathrm{NO}_{2}\right)_{2}\right](\mathrm{NT}) \cdot \mathrm{H}_{2} \mathrm{O}(7)$. All tested samples showed excellent long-term storage and lowtemperature stability.

\section{Experimental section}

\section{General procedures}

The starting materials $\left[\mathrm{Co}\left(\mathrm{NH}_{3}\right)_{5} \mathrm{NO}_{2}\right] \mathrm{Cl}_{2},{ }^{36}\left[\mathrm{Co}\left(\mathrm{NH}_{3}\right)_{4}(\mathrm{py}) \mathrm{NO}_{2}\right]$ $\mathrm{Cl}_{2}$ (py = pyridine), ${ }^{37}$ trans $-\left[\mathrm{Co}\left(\mathrm{NH}_{3}\right)_{4}\left(\mathrm{NO}_{2}\right)_{2}\right] \mathrm{Cl},{ }^{38}\left[\mathrm{Co}\left(\mathrm{NH}_{3}\right)_{5} \mathrm{~N}_{3}\right]-$ $\mathrm{Cl}_{2},{ }^{13}\left[\mathrm{Co}(\mathrm{en})(\mathrm{py})_{2}\left(\mathrm{NH}_{3}\right) \mathrm{Cl}\right] \mathrm{Cl}_{2} \cdot \mathrm{H}_{2} \mathrm{O},{ }^{34} \mathrm{Na}_{2} \mathrm{C}_{2} \mathrm{~N}_{10} \cdot 5 \mathrm{H}_{2} \mathrm{O}, \quad(\mathbf{1}),{ }^{20}$ and NaNT $(6)^{21 e, 25}$ were prepared according to published procedures. Picric acid, dipicrylamide and $\mathrm{NaN}_{3}$ were obtained from commercial sources and used as received. IR $(\mathrm{KBr})$ spectra were measured using a Perkin-Elmer FT-IR 2000 spectrometer. NMR spectra were recorded on a DPX 400 (Bruker) or AVANCE 600 (Bruker-Biospin) spectrometer. Microanalyses of the compounds were performed using Leco CHNS 023 apparatus.

\section{Single crystal X-ray crystallography}

The intensity data of $2,3,4,5,7,10$, and 13 were collected on a Stoe IPDS $2 \mathrm{~T}$ diffractometer with $\mathrm{MoK}_{\alpha}$ radiation. The data were collected with the Stoe XAREA ${ }^{39}$ program using $\omega$-scans. The space groups were determined with the XRED32 ${ }^{39}$ program. The intensity data of $\mathbf{9}$ and $\mathbf{1 2}$ were registered on an Oxford Diffraction Nova A diffractometer using mirror-focused
$\mathrm{CuK}_{\alpha}$ radiation. Absorption corrections were applied using the multi-scan method. The structures were solved by direct methods (SHELXS-97) and refined by full matrix least-squares methods on $F^{2}$ using SHELXL-97. ${ }^{40}$

Cautionary note

All compounds described in this study are sensitive energetic materials which should only be synthesized and manipulated on a small (<250 mg) scale using proper safety equipment including thick leather gloves and jackets, face shields and blast screens, ear plugs and plastic or Teflon laboratory equipment. Care should be taken not to extensively dry or heat these materials as the anhydrous complexes are even more sensitive and prone to explosion on manipulation. In particular, the non-electrolyte complex 13 is extremely sensitive to impact and friction and should be handled with utmost care.

Synthesis of pentaammine-nitro-cobalt(III)-azotetrazolatedihydrate, $\left[\mathrm{Co}\left(\mathrm{NH}_{3}\right)_{5} \mathbf{N O}_{2}\right]\left(\mathrm{C}_{2} \mathbf{N}_{10}\right) \cdot 2 \mathbf{H}_{2} \mathrm{O}$ (2). To a solution of pentaammine-nitro-cobalt(III)-chloride $(0.20 \mathrm{~g}, 0.77 \mathrm{mmol})$ in a minimum amount of warm water $\left(40{ }^{\circ} \mathrm{C}, \mathrm{ca} .10 \mathrm{~mL}\right)$ was added $0.24 \mathrm{~g}$ (0.80 mmol) $\mathrm{Na}_{2} \mathrm{C}_{2} \mathrm{~N}_{10} \cdot 5 \mathrm{H}_{2} \mathrm{O}$ (1) in $10 \mathrm{~mL}$ water. Undisturbed standing at r.t. for $24 \mathrm{~h}$ afforded large, clear yellow crystals suitable for X-ray diffraction (Fig. 1). Yield: $0.23 \mathrm{~g}$ (74\%). M.p. > $290{ }^{\circ} \mathrm{C}$ (violent dec.). ${ }^{13} \mathrm{C}\left\{{ }^{1} \mathrm{H}\right\}$ NMR $(100.6 \mathrm{MHz}$, DMSO- $\left.d_{6}, 20^{\circ} \mathrm{C}\right): \delta 173.1\left(\left[\mathrm{~N}_{4} C-\mathrm{N}=\mathrm{N}-C_{4}\right]^{2-}\right)$. IR $\left(\mathrm{KBr}, \mathrm{cm}^{-1}\right)$ : $\nu_{\text {max }} 3431$ (vs), 2106 (m), 1628 (m), 1452 (s), 1402 (s), 1202 (m), 1164 (m), 1065 (m), 1042 (m), 866 (m), 775 (m), 740 (s), 564 (s). Anal. Calcd for $\mathrm{C}_{2} \mathrm{H}_{19} \mathrm{CoN}_{16} \mathrm{O}_{4}\left(392.23 \mathrm{~g} \mathrm{~mol}^{-1}\right)$ : C, 6.16; $\mathrm{H}$, 4.91; N, 57.43. Found: C, 6.02; H, 4.76; N, 56.78.

Synthesis of trans-tetraammine-nitro-pyridine-cobalt(III)azotetrazolate-dihydrate, $\left[\mathrm{Co}\left(\mathrm{NH}_{3}\right)_{5} \mathrm{NO}_{2}\right]\left(\mathrm{C}_{2} \mathbf{N}_{10}\right) \cdot 2 \mathrm{H}_{2} \mathrm{O}$ (3). In a similar manner, trans-tetraammine-nitro-pyridine-cobalt(III)dichloride $(0.11 \mathrm{~g}, 0.34 \mathrm{mmol})$ was allowed to react with $0.10 \mathrm{~g}$ (0.33 mmol) $\mathrm{Na}_{2} \mathrm{C}_{2} \mathrm{~N}_{10} \cdot 5 \mathrm{H}_{2} \mathrm{O}$ (1) in ca. $15 \mathrm{~mL}$ water. Undisturbed standing at r.t. for $24 \mathrm{~h}$ afforded yellow-orange crystals suitable for X-ray diffraction (Fig. 4). Yield: $0.21 \mathrm{~g}$ (46\%). M.p. $>$ 260-263 ${ }^{\circ} \mathrm{C}$ (violent dec.). ${ }^{13} \mathrm{C}\left\{{ }^{1} \mathrm{H}\right\}$ NMR (100.6 MHz, DMSO$\left.d_{6}, 20{ }^{\circ} \mathrm{C}\right): \delta 173.1\left(\left[\mathrm{~N}_{4} C-\mathrm{N}=\mathrm{N}-C \mathrm{~N}_{4}\right]^{2-}\right), 158.2$ (2 C, py), 135.1 (1 C, py), 127.2 (2 C, py). IR (KBr, $\mathrm{cm}^{-1}$ ): $\nu_{\max } 3544$ (vs), 3430 (vs), 2445 (m), 2108 (m), 1626 (s), 1506 (m), 1452 (m), 1403 (s), 1203 (m), 1165 (m), 1096 (m), 1064 (m), 1043 (m), 776 (m), 741 (s), 566 (s). Anal. Calcd for $\mathrm{C}_{7} \mathrm{H}_{21} \mathrm{CoN}_{16} \mathrm{O}_{4}\left(452.28 \mathrm{~g} \mathrm{~mol}^{-1}\right)$ : C, 18.59; H, 4.68; N, 49.55. Found: C, 20.01; H, 4.20; N, 49.37.

Synthesis of bis[trans-tetraammine-dinitro-cobalt(III)]-azotetrazolate, trans- $\left[\mathrm{Co}\left(\mathrm{NH}_{3}\right)_{4}\left(\mathrm{NO}_{2}\right)_{2}\right]_{2}\left(\mathrm{C}_{2} \mathbf{N}_{10}\right) \quad$ (4). Reaction

Table 2 Energetic properties of 2, 3, 4, 5, 7, 9, and 10

\begin{tabular}{|c|c|c|c|c|c|c|c|}
\hline Compound & 2 & 3 & 4 & 5 & 7 & 9 & 10 \\
\hline$M\left(\mathrm{~g} \mathrm{~mol}^{-1}\right)$ & 392.23 & 452.28 & 602.22 & 368.21 & 351.12 & 465.18 & 642.30 \\
\hline$\rho, \mathrm{g} \mathrm{cm}^{-3}$ & 1.605 & 1.671 & 1.989 & 1.726 & 1.958 & 1.869 & 1.844 \\
\hline Impact sensitivity/J & 8 & $>10$ & 8 & $3.5-5$ & 5 & 8 & 7.5 \\
\hline Friction sensitivity (N) & $>216$ & $>360$ & $>216$ & 216 & $>216$ & $>216$ & $>216$ \\
\hline Combustion test & Deflagr. & Explosion & Explosion & Explosion & Deflagr. & Explosion & Explosion \\
\hline$N(\%)$ & $57.43^{\circ}$ & 49.55 & 51.17 & 68.47 & $43.88^{\circ}$ & 27.10 & 30.53 \\
\hline$\Omega(\%)$ & -55.87 & -82.64 & -26.56 & -49.97 & -13.67 & -30.95 & -26.15 \\
\hline
\end{tabular}


between trans- $\left[\mathrm{Co}\left(\mathrm{NH}_{3}\right)_{4}\left(\mathrm{NO}_{2}\right)_{2}\right] \mathrm{Cl}(0.20 \mathrm{~g}, 0.79 \mathrm{mmol})$ and 1 $(0.11 \mathrm{~g}, 0.37 \mathrm{mmol})$ afforded $0.19 \mathrm{~g}(87 \%) 4$ as clear yellow single-crystals suitable for X-ray diffraction (Fig. 7). M.p. $>250{ }^{\circ} \mathrm{C}$ (violent dec.). ${ }^{13} \mathrm{C}\left\{{ }^{1} \mathrm{H}\right\}$ NMR $\left(100.6 \mathrm{MHz}\right.$, DMSO- $d_{6}$, $\left.20{ }^{\circ} \mathrm{C}\right): \delta 173.1\left(\left[\mathrm{~N}_{4} \mathrm{C}-\mathrm{N}=\mathrm{N}-\mathrm{CN}_{4}\right]^{2-}\right)$. IR $\left(\mathrm{KBr}, \mathrm{cm}^{-1}\right): \nu_{\max }$ $3331(\mathrm{~m}), 2445(\mathrm{~m}), 2106(\mathrm{~m}), 1628(\mathrm{~m}), 1452(\mathrm{~m}), 1375(\mathrm{~s})$, $1202(\mathrm{~m}), 1164(\mathrm{~m}), 1065$ (m), 1042 (m), 866 (m), $775(\mathrm{~m})$, $740(\mathrm{~m}), 692(\mathrm{~m}), 564(\mathrm{~m}), 464(\mathrm{~m})$. Anal. Calcd for $\mathrm{C}_{2} \mathrm{H}_{24} \mathrm{Co}_{2} \mathrm{~N}_{22} \mathrm{O}_{8}\left(602.22 \mathrm{~g} \mathrm{~mol}^{-1}\right): \mathrm{C}, 3.99 ; \mathrm{H}, 4.02 ; \mathrm{N}, 51.17$. Found: C, 3.68; H, 4.10; N, 53.01.

Synthesis of pentaammine-azido-cobalt(III)-azotetrazolatemonohydrate, $\left[\mathrm{Co}\left(\mathrm{NH}_{3}\right)_{5} \mathbf{N}_{3}\right]\left(\mathbf{C}_{2} \mathbf{N}_{10}\right) \cdot \mathbf{H}_{2} \mathbf{O}$ (5). Reaction between $\left[\mathrm{Co}\left(\mathrm{NH}_{3}\right)_{5} \mathrm{~N}_{3}\right] \mathrm{Cl}_{2}(0.35 \mathrm{~g}, 1.37 \mathrm{mmol})$ and $\mathbf{1}(0.41 \mathrm{~g}, 1.37 \mathrm{mmol})$ afforded a deep purple reaction mixture from which $\mathbf{5}$ crystallized after 1 day in the form of purple, rod-like single-crystals which were suitable for X-ray diffraction (Fig. 10). Yield: $0.44 \mathrm{~g}$ (88\%). M.p. $256{ }^{\circ} \mathrm{C}$ (violent dec.). $\left.{ }^{13} \mathrm{C}^{1}{ }^{1} \mathrm{H}\right\}$ NMR $(100.6 \mathrm{MHz}$, DMSO- $\left.d_{6}, 20^{\circ} \mathrm{C}\right): \delta 173.2\left(\left[\mathrm{~N}_{4} C-\mathrm{N}=\mathrm{N}-\mathrm{CN}_{4}\right]^{2-}\right)$. IR $\left(\mathrm{KBr}, \mathrm{cm}^{-1}\right)$ : $\nu_{\max } 3275$ (vs), 2346 (s), 2050 (vs), 1631 (vs), 1558 (vs), 1385 (vs), 1315 (vs), 1152 (s), 1041 (s), 830 (vs), 771 (vs), 734 (vs), 557 (s). Anal. Calcd for $\mathrm{C}_{2} \mathrm{H}_{17} \mathrm{CoN}_{18} \mathrm{O}\left(368.21 \mathrm{~g} \mathrm{~mol}^{-1}\right)$ : C, 6.52; $\mathrm{H}$, $4.65 ; \mathrm{N}, 68.47$. Found: C, 6.66; H, 4.02; N, 70.99.

Synthesis of trans-tetraammine-dinitro-cobalt(III)-5-nitrotetrazolate-monohydrate, trans $-\left[\mathrm{Co}\left(\mathrm{NH}_{3}\right)_{4}\left(\mathrm{NO}_{2}\right)_{2}\right](\mathrm{NT}) \cdot \mathrm{H}_{2} \mathrm{O}$ (7). Similar treatment of trans-[Co( $\left.\left(\mathrm{NH}_{3}\right)_{4}\left(\mathrm{NO}_{2}\right)_{2}\right] \mathrm{Cl}(0.15 \mathrm{~g}$, $0.58 \mathrm{mmol})$ with $6(0.10 \mathrm{~g}, 0.58 \mathrm{mmol})$ in a minimum amount of water (ca. $10 \mathrm{~mL}$ ) afforded $0.10 \mathrm{~g}(64 \%)$ of 7 as orange, block-like single crystals with a somewhat milky appearance (Fig. 13), which were nevertheless suitable for X-ray diffraction. M.p. ca. $230{ }^{\circ} \mathrm{C}$ (violent dec.). ${ }^{13} \mathrm{C}\left\{{ }^{1} \mathrm{H}\right\}$ NMR $\left(100.6 \mathrm{MHz}, \mathrm{D}_{2} \mathrm{O}\right.$, $\left.20{ }^{\circ} \mathrm{C}\right): \delta 165.2\left(1 \mathrm{C}, \mathrm{NO}_{2}-\mathrm{CN}_{4}\right) . \mathrm{IR}\left(\mathrm{KBr}, \mathrm{cm}^{-1}\right): \nu_{\max } 3306(\mathrm{~s})$, 1622 (m), 1550 (s), 1385 (vs), 1322 (vs), 1282 (s), 819 (m), $623(\mathrm{~m}), 503(\mathrm{~m})$. Anal. Calcd for $\mathrm{CH}_{14} \mathrm{CoN}_{11} \mathrm{O}_{7}\left(351.12 \mathrm{~g} \mathrm{~mol}^{-1}\right)$ : C, 3.42; H, 4.02; N, 43.88. Found: C, 3.09; H, 3.88; N, 42.90.

Synthesis of trans-tetraammine-dinitro-cobalt(III)-picratemonohydrate, trans- $\left[\mathrm{Co}\left(\mathrm{NH}_{3}\right)_{4}\left(\mathrm{NO}_{2}\right)_{2}\right]($ picrate $) \cdot \mathrm{H}_{2} \mathrm{O}$ (9). Reaction of trans $-\left[\mathrm{Co}\left(\mathrm{NH}_{3}\right)_{4}\left(\mathrm{NO}_{2}\right)_{2}\right] \mathrm{Cl}(0.10 \mathrm{~g}, 0.39 \mathrm{mmol})$ with sodium picrate $(0.39 \mathrm{mmol}$, made in situ from $0.09 \mathrm{~g}$ of picric acid and $\mathrm{NaOH}$ ) in a minimum amount of water $(c a .10 \mathrm{~mL})$ first gave an orange precipitate. Recrystallization of the crude product from hot water $(c a .8 \mathrm{~mL})$ afforded $0.12 \mathrm{~g}(66 \%)$ of 9 as orange, block-like single-crystals (Fig. 16) which were suitable for X-ray diffraction. M.p. ca. $285{ }^{\circ} \mathrm{C}$ (violent dec.). ${ }^{13} \mathrm{C}\left\{{ }^{1} \mathrm{H}\right\}$ NMR $\left(20{ }^{\circ} \mathrm{C}, \mathrm{D}_{2} \mathrm{O}, 100 \mathrm{MHz}\right): \delta\left(100.6 \mathrm{MHz}, \mathrm{D}_{2} \mathrm{O}, 20{ }^{\circ} \mathrm{C}\right): \delta$ 160.9 (1 C; C1), 141.9 (2 C; C2, C6), 125.3 (2 C; C3, C5), 124.3 (1 C; C4). IR (KBr, cm $\left.{ }^{-1}\right): \nu_{\max } 3629(\mathrm{~m}), 3522$ (s), 3308 (vs), 1635 (vs), 1556 (vs), 1510 (s), 1474 (s), 1435 (s), 1400 (vs), 1366 (vs), 1321 (vs), 1250 (s), 1162 (s), 1086 (s), 946 (m), 929 (m), 911 (m), $818(\mathrm{~s}), 789(\mathrm{~m}), 747(\mathrm{~m}), 709(\mathrm{~s}), 602(\mathrm{~m}), 507(\mathrm{~m})$. Anal. Calcd for $\mathrm{C}_{6} \mathrm{H}_{16} \mathrm{CoN}_{9} \mathrm{O}_{12}\left(465.18 \mathrm{~g} \mathrm{~mol}^{-1}\right)$ : C, $15.49 ; \mathrm{H}, 3.47 ; \mathrm{N}$, 27.10. Found: C, $15.45 ; \mathrm{H}, 3.67 ; \mathrm{N}, 27.10$.

Synthesis of pentaammine-azido-cobalt(III)-dipicrate, [Co$\left.\left(\mathbf{N H}_{3}\right)_{5} \mathbf{N}_{3}\right]$ (picrate $)_{2}$ (10). Analogous reaction of $\left[\mathrm{Co}\left(\mathrm{NH}_{3}\right)_{5} \mathrm{~N}_{3}\right]-$ $\mathrm{Cl}_{2}(0.10 \mathrm{~g}, 0.39 \mathrm{mmol})$ with sodium picrate $(0.78 \mathrm{mmol}$, made in situ from $0.18 \mathrm{~g}$ of picric acid and $\mathrm{NaOH}$ ) in a minimum amount of water $(c a .10 \mathrm{~mL})$ afforded a dark red-purple pre- cipitate. Recrystallization from hot water $(c a .10 \mathrm{~mL})$ gave $0.22 \mathrm{~g}(87 \%)$ of $\mathbf{1 0}$ as clear, dark red, rod-like single-crystals (Fig. 19) which were suitable for X-ray diffraction. M.p. ca. $195{ }^{\circ} \mathrm{C}$ (violent dec.). ${ }^{13} \mathrm{C}\left\{{ }^{1} \mathrm{H}\right\}$ NMR $\left(100.6 \mathrm{MHz}, \mathrm{D}_{2} \mathrm{O}, 20{ }^{\circ} \mathrm{C}\right.$ ): $\delta 160.9$ (1 C; C1), 141.8 (2 C; C2, C6), 125.3 (2 C; C3, C5), 124.0 (1 C; C4). IR (KBr, cm ${ }^{-1}$ ): $\nu_{\max } 3271$ (vs), 2056 (vs), 1639 (s), 1554 (s), 1433 (m), 1368 (m), 1320 (vs), 1285 (s), 1163 (m), $1083(\mathrm{~m}), 910(\mathrm{~m}), 843(\mathrm{~s}), 747(\mathrm{~m}), 712(\mathrm{~m}), 662(\mathrm{~m}), 579(\mathrm{~m})$, $463(\mathrm{~m})$. Anal. Calcd for $\mathrm{C}_{12} \mathrm{H}_{19} \mathrm{CoN}_{14} \mathrm{O}_{14}\left(642.30 \mathrm{~g} \mathrm{~mol}^{-1}\right)$ : C, 22.44; H, 2.98; N, 30.53. Found: C, 23.40; H, 3.04; N, 30.48.

Synthesis of trans-tetraammine-dinitro-cobalt(III)-dipicrylamide-monohydrate, trans- $\left[\mathrm{Co}\left(\mathrm{NH}_{3}\right)_{4}\left(\mathrm{NO}_{2}\right)_{2}\right](\mathrm{DPA}) \cdot \mathrm{H}_{2} \mathrm{O}(12)$. To a suspension of dipicrylamine $(1.0 \mathrm{~g}, 2.27 \mathrm{mmol})$ in $10 \mathrm{~mL}$ water were added two pellets of solid $\mathrm{NaOH}$ to give a dark red solution of NaDPA. ${ }^{33}$ A concentrated solution of trans-[Co$\left.\left(\mathrm{NH}_{3}\right)_{4}\left(\mathrm{NO}_{2}\right)_{2}\right] \mathrm{Cl}(0.58 \mathrm{~g}, 2.27 \mathrm{mmol})$ in $10 \mathrm{~mL}$ water was added and the dark red reaction mixture was allowed to stand undisturbed for 1 week. This produced bright orange crystals of 12 in $53 \%$ yield $\left(0.42\right.$ g). M.p. > $350{ }^{\circ} \mathrm{C}$ (dec.). IR ( $\left.\mathrm{KBr}, \mathrm{cm}^{-1}\right)$ : $\nu_{\max } 3436(\mathrm{~m}), 3360(\mathrm{~m}), 2430(\mathrm{w}), 1790(\mathrm{~m}), 1665(\mathrm{~m}), 1587(\mathrm{~s})$, 1498 (m), 1383 (vs), 1320 (vs), 1300 (s), 1262 (m), 1982 (m), $910(\mathrm{w}), 836(\mathrm{~m}), 768(\mathrm{w}), 740(\mathrm{w}), 719(\mathrm{~m}), 509$ (w). Anal. Calcd for $\mathrm{C}_{24} \mathrm{H}_{38} \mathrm{Co}_{2} \mathrm{~N}_{26} \mathrm{O}_{35}\left(1368.59 \mathrm{~g} \mathrm{~mol}^{-1}\right)$ : C, 21.06; $\mathrm{H}, 2.80$; N, 26.61. Found: C, 21.00; H, 2.55; N, 24.98.

Synthesis of mer-triazido-ethylenediamine-pyridine-cobalt(III), mer-[Co(en)(py)( $\left.\left.\mathrm{N}_{3}\right)_{3}\right](13) .0 .30 \mathrm{~g}(0.72 \mathrm{mmol})$ of $[\mathrm{Co}(\mathrm{en})-$ (py) $\left.)_{2}\left(\mathrm{NH}_{3}\right) \mathrm{Cl}\right] \mathrm{Cl}_{2} \cdot \mathrm{H}_{2} \mathrm{O}$ were dissolved in $25 \mathrm{~mL} \mathrm{H}_{2} \mathrm{O}$ and $1.00 \mathrm{~g}$ (15.38 mmol) $\mathrm{NaN}_{3}$ was added as a solid. The reaction mixture was heated in a steam bath without stirring until the water had evaporated completely. During this time the color of the solution changed from red to dark green and the smell of pyridine became evident. The residue was swirled five times with $20 \mathrm{~mL}$-portions of water and the aqueous solutions were carefully decanted in order to redissolve and separate the unreacted $\mathrm{NaN}_{3}$. After drying the residue in air, $0.22 \mathrm{~g}(93 \%)$ of 13 were obtained as dark blue-green, feather-like crystals. Due to its highly explosive nature, melting/decomposition point, IR spectra, and elemental analysis data could not be obtained for 13. Anal. Calcd for $\mathrm{C}_{7} \mathrm{H}_{13} \mathrm{CoN}_{12}\left(324.19 \mathrm{~g} \mathrm{~mol}^{-1}\right)$ : C, 25.93; $\mathrm{H}, 4.04 ; \mathrm{N}, 51.85$.

\section{Acknowledgements}

Financial support by the Otto-von-Guericke-Universität Magdeburg is gratefully acknowledged.

\section{Notes and references}

1 (a) J. Boileau, in Explosives, Ullmanns Encyclopedia of Industrial Chemistry, Wiley-Interscience, 2003; (b) J. Köhler, R. Meyer and A. Homburg, Explosivstoffe, Wiley-VCH, Weinheim, 10th edn, 2008; (c) T. M. Klapötke, Chemistry of HighEnergy Materials, Walter de Gruyter, Berlin/New York, 2011, and references cited therein. 
2 W. Beck, J. Evers, M. Göbel, G. Oehlinger and T. M. Klapötke, Z. Anorg. Allg. Chem., 2007, 633, 1417-1422, and references cited therein.

3 (a) T. Curtius, Chem. Ber., 1891, 24, 3345-3346; (b) T. Urbanski, Chemistry and Technology of Explosives, Macmillan Publishing Company, Oxford, U.K., 1967, vol. 4; (c) T. Costain and F. B. Wells, in Energetic Materials, Vol. 2: Technology of the Inorganic Azides, ed. H. D. Fair and R. F. Walker, Plenum Press, New York, NY, USA, 1977.

4 E. V. Herz, Beilstein, 1914, 6, 405.

5 M. E. Barsan and A. Miller, Lead Health Hazard Evaluation, HETA Report No. 91-0346-2572, National Institute for Occupational Safety and Health, Cincinnati, Ohia, 1996.

6 (a) J. Giles, Nature, 2004, 427, 581-582; (b) M. H. V. Huynh, M. A. Hiskey, T. J. Meyer and M. Wetzler, Proc. Natl. Acad. Sci. U. S. A., 2006, 103, 5409-5412; (c) M. H. V. Huynh, M. D. Coburn, T. J. Meyer and M. Wetzler, Proc. Natl. Acad. Sci. U. S. A., 2006, 103, 10322-10327.

7 (a) H. Xue, Y. Gao, B. Twamley and J. M. Shreeve, Inorg. Chem., 2005, 44, 5068-5072; (b) C. Ye, J.-C. Xiao, B. Twamley and J. M. Shreeve, Chem. Commun., 2005, 27502752; (c) R. P. Singh, R. D. Verma, D. T. Meshri and J. M. Shreeve, Angew. Chem., Int. Ed., 2006, 45, 3584-3601; (d) G. Steinhauser and T. M. Klapötke, Angew. Chem., Int. Ed., 2008, 47, 3330-3347; (e) H. Gao and J. M. Shreeve, Chem. Rev., 2011, 111, 7377-7436; (f) Q. Zhang and J. M. Shreeve, Angew. Chem., Int. Ed., 2013, 52, 8792-8794.

8 J. W. Fronabarger, M. D. Williams, W. B. Sanborn, J. G. Bragg, D. A. Parrish and M. Bichay, Propellants Explos., Pyrotech., 2011, 36, 541-550.

9 E. J. Graeber and B. Morosin, Acta Crystallogr., Sect. C: Cryst. Struct. Commun., 1983, 39, 567-570.

10 A. V. Smirnov, M. A. Ilyushin and I. V. Tselinskii, Russ. J. Appl. Chem., 2004, 77, 794-796.

11 (a) B. Morosin, R. G. Dunn, R. Assink, T. M. Massis, J. Fronabarger and E. N. Duesler, Acta Crystallogr., Sect. C: Cryst. Struct. Commun., 1997, 53, 1609-1611; (b) A. Yu. Zhilin, M. A. Ilyushin, I. V. Tselinskii and A. S. Brykov, Russ. J. Appl. Chem., 2001, 74, 96-99.

12 J. Sass, Int. J. Occup. Environ. Health, 2004, 10, 330-334.

13 M. Linhard and H. Flygare, Z. Anorg. Allg. Chem., 1950, 262, 328-343.

14 M. Linhard, M. Weigel and H. Flygare, Z. Anorg. Allg. Chem., 1950, 263, 233-244.

15 P. J. Staples and M. L. Tobe, J. Chem. Soc., 1960, 4812-4820.

16 H. Siebert and R. Macht, Z. Anorg. Allg. Chem., 1982, 489, 77-84.

17 L. F. Druding, F. D. Sancilio and D. M. Lukaszewski, Inorg. Chem., 1975, 14, 1365-1369.

18 M. Linhard and M. Weigel, Z. Anorg. Allg. Chem., 1950, 263, 245-252.

19 Selected references: (a) A. Hammerl, T. M. Klapötke, H. Nöth, M. Warchhold, G. Holl, M. Kaiser and U. Ticmanis, Inorg. Chem., 2001, 40, 3570-3575; (b) A. Hammerl, G. Holl, T. M. Klapötke, P. Mayer, H. Nöth,
H. Piotrowski and M. Warchhold, Eur. J. Inorg. Chem., 2002, 834-845, and references cited therein; (c) A. Hammerl, M. A. Hiskey, G. Holl, T. M. Klapötke, K. Polborn, J. Stiersdorfer and J. J. Weigand, Chem. Mater., 2005, 17, 3784-3793; (d) T. M. Klapötke and C. M. Sabaté, Chem. Mater., 2008, 20, 1750-1763; (e) T. M. Klapötke and C. M. Sabaté, New J. Chem., 2009, 33, 1605; (f) G.-H. Tao, B. Twamley and J. Shreeve, Inorg. Chem., 2009, 48, 99189923; $(g)$ G. Steinhauser, G. Giester, N. Leopold, C. Wagner, M. Villa and A. Musilek, Helv. Chim. Acta, 2010, 93, 183202; (h) K. F. Warner and R. H. Granholm, J. Energ. Mater., 2011, 29, 1-6.

20 J. Thiele, Liebigs Ann., 1898, 303, 57-75.

21 (a) T. M. Klapötke, K. Karaghiosoff, P. Mayer, A. Penger and J. M. Welch, Propellants Explos., Pyrotech., 2006, 31, 188-195; (b) C. Darwich, T. M. Klapötke, J. M. Welch and M. Suceska, Propellants Explos., Pyrotech., 2007, 32, 235-243; (c) T. M. Klapötke, C. M. Sabaté and M. Rasp, J. Mater. Chem., 2009, 19, 2240-2252; (d) T. M. Klapötke, C. M. Sabaté and J. M. Welch, Heteroat. Chem., 2009, 20, 35-44; (e) T. M. Klapötke, C. M. Sabaté and J. M. Welch, Eur. J. Inorg. Chem., 2009, 769-776.

22 (a) J. Charalambous, G. C. Georgiou, K. Henrick, L. R. Bates and M. Healey, Acta Crystallogr., Sect. C: Cryst. Struct. Commun., 1987, C43, 659-661; (b) B. Morosin, R. G. Dunn, R. Assink, T. M. Massis, J. Fronabarger and E. N. Duesler, Acta Crystallogr., Sect. C: Cryst. Struct. Commun., 1997, C53, 1609-1611; (c) A. Y. Zhilin, M. A. Ilyushin, I. V. Tselinski and A. S. Brykov, Russ. J. Appl. Chem., 2001, 74, 99-102; (d) M. H. V. Huynh, M. A. Hiskey, T. J. Meyer and M. Wetzler, Proc. Natl. Acad. Sci. U. S. A., 2006, 103, 5409-5412; (e) M. H. V. Huynh, M. D. Coburn, T. J. Meyer and M. Wetzler, Proc. Natl. Acad. Sci. U. S. A., 2006, 103, 10322-10327; $(f)$ T. M. Klapötke and C. M. Sabaté, Dalton Trans., 2009, 1835-1841; (g) T. M. Klapötke and C. M. Sabaté, Cent. Eur. J. Energ. Mater., 2010, 7, 161-173.

23 G. Stock, C. G. Hrib, R. Deblitz, M. Kühling, G. Plenikowski and F. T. Edelmann, Inorg. Chem. Commun., 2014, 43, 90-93.

24 (a) T. M. Klapötke, C. M. Sabaté and J. M. Welch, Dalton Trans., 2008, 6372-6380; (b) N. Zaborenko, E. R. Murphy, J. G. Kralj and K. F. Jensen, Ind. Eng. Chem. Res., 2010, 49, 4132-4139; (c) T. M. Klapötke, D. G. Piercey, N. Mehta, K. D. Oyler, M. Jorgensen, S. Lenahan, J. S. Salan, J. W. Fronabarger and M. D. Williams, Z. Anorg. Allg. Chem., 2013, 639, 681-688.

25 (a) E. von Herz, US Patent, 2,066,954, 1937; (b) W. H. Gilligan and M. J. Kamlet, US Patent, 4,093,623, 1978.

26 (a) G. Singh, I. P. S. Kapoor, M. Mannan and S. K. Tiwari, J. Hazard. Mater., 1999, 68, 155-178; (b) G. Singh, I. P. S. Kapoor, S. M. Mannan and J. Kaur, J. Hazard. Mater., 2000, 79, 1-18, and references cited therein.

27 C.-M. Jin, C. Ye, C. Piekarski, B. Twamley and J. M. Shreeve, Eur. J. Inorg. Chem., 2005, 3760-3767. 
28 F. Ephraim, Ber. Dtsch. Chem. Ges., 1923, 56, 1530-1542.

29 (a) S. Eringathodi, P. Agnihotri, B. Ganguly, P. Bhatt, P. S. Subramanian, P. Paul and P. K. Gosh, Eur. J. Inorg. Chem., 2005, 2198-2205; (b) P. Agnihotri, S. Patra, E. Suresh, P. Paul and P. K. Ghosh, Eur. J. Inorg. Chem., 2006, 4938-4944; (c) H. Huang, Z. Zhou, J. Song, L. Liang, K. Wang, D. Cao, W. Sun, X. Dong and M. Xue, Chem. Eur. J., 2011, 17, 13593-13602.

30 (a) R. Gnehm, Ber. Dtsch. Chem. Ges., 1874, 7, 1399-1401; (b) R. Gnehm, Ber. Dtsch. Chem. Ges., 1876, 9, 1245-1246.

31 (a) I. Rokstad, Acta Derm. Venerol., 1946, 26, 350; (b) F. Seifert, Vom Wasser, 1949, 17, 89-92; (c) J. Kjelland, Chem. Ind., 1971, 1309-1313.

32 (a) A. Winkel and D. I. H. Maas, Angew. Chem., Int. Ed. Engl., 1936, 49, 827-830; (b) L. A. Bray, E. C. Martin, R. L. Moore and W. A. Richland, U. S. Atomic Energy Commun., HW-SA-2620, 1962, p. 8.
33 (a) M. Kyrs, J. Pelcik and P. Polansky, Collect. Czechoslov. Chem. Commun., 1960, 25, 2642; (b) V. Kourim and J. Krtil, Proc. U. N. Intern. Conf. Peaceful Uses Atomic Energy, Geneva, 2nd edn, 1958, vol. 28, p. 139.

34 F. Edelmann and U. Behrens, Z. Anorg. Allg. Chem., 1977, 432, 58-66.

35 N. Mehta, K. Oyler, G. Cheng, A. Shah, J. Marin and K. Yee, Z. Anorg. Allg. Chem., 2014, 640, 1309-1313.

36 S. M. Jörgensen, Z. Anorg. Allg. Chem., 1894, 5, 174-196.

37 A. Ganiev, Zh. Neorg. Khim., 1962, 7, 261-264.

38 S. M. Jörgensen, Z. Anorg. Allg. Chem., 1898, 17, 455-479.

39 Stoe, XAREA Program for Xray Crystal Data collection, (XRED32 included in XAREA), Stoe, 2002.

40 (a) G. M. Sheldrick, SHELXL-97 Program for Crystal Structure Refinement, Universität Göttingen, Germany, 1997; (b) G. M. Sheldrick, SHELXS-97 Program for Crystal Structure Solution, Universität Göttingen, Germany, 1997. 